\title{
Klinik Uygulamalarda İleri Biyomedikal Görüntüleme Teknolojileri
}

\author{
Raziye Kübra Kumrular ${ }^{*}$, Adem Polat $^{2}$ \\ 1* University of Southampton, The Faculty of Engineering and Physical Sciences, Southampton, United Kingdom (ORCID: 0000-0002-0976-3683), \\ kubra.kumrular@gmail.com \\ ${ }^{2}$ Çanakkale Onsekiz Mart Üniversitesi, Mühendislik Fakültesi, Elektronik Mühendisliği Bölümü, Çanakkale, Türkiye (ORCID: 0000-0002-5662-4141), \\ adempolat@comu.edu.tr
}

(İlk Geliş Tarihi 18 Aralık 2020 ve Kabul Tarihi 20 Mart 2021)

(DOI: 10.31590 /ejosat.840321)

\begin{abstract}
ATIF/REFERENCE: Kumrular, R. K. \& Polat, A. (2021). Klinik Uygulamalarda İleri Biyomedikal Görüntüleme Teknolojileri. Avrupa Bilim ve Teknoloji Dergisi, (23), 207-221.

Öz

Hastalıkların tıbbi tanı ve tedavisinde görüntüleme çok önemli bir yer tutmaktadır. Biyomedikal görüntüleme teknolojileri sayesinde, vücudun içini invaziv olmayan yöntemlerle görüntüleyen tıbbi görüntüleme araçları geliştirilmiştir. Günümüz klinik uygulamalarındaki görüntüleme teknikleri ile iyonize ve iyonize olmayan radyasyonun, insan vücuduyla etkileşimi kullanılarak yüksek çözünürlükte tıbbi görüntüler üretilmektedir. Bu makalede hali hazırda kullanılan ileri biyomedikal görüntüleme teknolojileri kapsamında; Röntgen (X-ray) görüntüleme (X-ray radyografisi), bilgisayarlı tomografi (BT), sayısal meme tomosentezi (DBT), manyetik rezonans görüntüleme (MRI), fonksiyonel manyetik rezonans görüntüleme (fMRI), tek foton emisyonlu bilgisayarlı tomografi (SPECT), pozitron emisyon tomografi (PET), ultrason görüntüleme, Doppler ultrason, elektrik empedansı tomografisi (EIT) ve kızı̈ötesi termal görüntüleme (IRT) sırasıyla incelenmiştir. Bu tekniklerin çalışma prensipleri, faydaları, riskleri, avantajları, dezavantajları ve uygulama alanları ayrıntılarıyla sunulmuştur. İncelenen teknikler için, görüntü kalitesi (mekânsal çözünürlük ve kontrast), radyasyonun vücuda etkisi (iyonizasyon seviyesi) ve sistemin kullanılabilirliği (gerçek zamanlı bilgi ve maliyeti) ve uygulama alanları hakkında karşılaştırmalı bilgiler verilmiştir.
\end{abstract}

Anahtar Kelimeler: Tıbbi Görüntüleme, X-ray (Röntgen) Görüntüleme, Bilgisayarlı Tomografi, Sayısal Meme Tomosentezi, Manyetik Rezonans Görüntüleme, COVID-19.

\section{Advanced Biomedical Imaging Technologies In Clinical Applications}

\begin{abstract}
Imaging has an important role in the medical diagnosis and treatment of diseases. Thanks to biomedical imaging technologies, medical imaging tools have been developed that image the inside of the body using non-invasive methods. High-resolution medical images are produced by using the interaction of ionizing and non-ionizing radiation with the human body with imaging techniques in today's clinical applications. In this article, within the scope of advanced biomedical imaging technologies currently used; Rontgen (X-ray) imaging (X-ray radiography), computed tomography (CT), digital breast tomosynthesis (DBT), magnetic resonance imaging (MRI), functional magnetic resonance imaging (fMRI), single-photon emission computed tomography (SPECT) Positron emission tomography (PET), ultrasound imaging, Doppler ultrasound, electrical impedance tomography (EIT), and infrared thermal imaging (IRT), respectively. The details of working principles, benefits, risks, advantages, disadvantages, and application areas of these techniques have been presented. For the examined techniques, comparative information about image quality (spatial resolution and contrast), the effect of radiation on the body (ionization level) and the usability (real-time information and cost) of the system and application areas have been given.
\end{abstract}

Keywords: Medical Imaging, X-ray (Roentgen) Imaging, Computed Tomography, Digital Breast Tomosynthesis, Magnetic Resonance Imaging, COVID-19

* Sorumlu Yazar: kubra.kumrular@gmail.com 


\section{Giriş}

Tıp bilimi, tüm sağlık, hastalık ve yaralanma durumlarında insan vücudunun yapısını ve işlevini anlamak, yorumlamak, yönetmek ve bunların sonucunda insan vücudu hakkında bilgi üretmektir. Biyolojik ve tıbbi süreçler hakkındaki bu bilgileri üretmek için insan vücudunun görüntülerinden yararlanmak, sadece klinik tıpta değil, onu destekleyen biyomedikal araştırma alanlarında da kullanılmaktadır. $\mathrm{Bu}$ sebeple biyomedikal görüntülemelerdeki ilerlemeler, günümüz elektronik ve bilgisayar teknolojisindeki gelişmeler sayesinde hız kazanmıştır (Ehman vd., 2007; Hendee \& Ritenour, 2003).

Modern biyomedikal görüntüleme yöntemlerinin temelini oluşturan ve tıp biliminde yeni bir çağın başlamasını sağlayan X1şınları 1895 yılı Kasım ayında Würzburg Üniversitesi'nde Alman fizik profesörü Wilhelm Conrad Röntgen tarafindan keşfedilmiştir. Fizik tarihinin en önemli makalelerinden biri olan "Yeni Bir Işın Üzerine" isimli makalesini yayınlayan Röntgen, X-1şınları buluşuyla 1901 'de ilk Nobel fizik ödülünü almıştır. Röntgen'in bu keşfi bilim dünyasında büyük bir yankı uyandırırken görüntüleme alanında yeni gelişmelerin de temellerini oluşturmuştur (Assmus, 1995; Gunderman, 2012). Röntgen'in buluşundan kısa bir zaman sonra Fransız fizikçi Henri Antonie Becquerel X-1şınları üzerinde çalışırken uranyumun radyoaktifliğini, Marie Curie ve eşi Pierre Curie ise radyum elementini keşfederek 'radyoloji' biliminin doğuşunu gerçekleştirmişler ve 1903 yılında radyoloji çalışmaları ile Nobel fizik ödülünü Curie çifti ve Becquerel paylaşmışlardır (Gunderman, 2012; Samei \& Peck, 2019).

Tıbbi görüntüler, X-1şını, gama 1şını, ultraviyole, optik, kızılötesi, mikrodalga, radyo frekansı, manyetik alan ve ultrason dalgaları gibi çeşitli kaynakların insan vücuduna nüfuz etme kabiliyetleri ve dokularla etkileşimleri sayesinde farklı proseslerle üretilmektedir (Wolbarst \& Hendee, 2006). Bu görüntüler Röntgen (X-ray) görüntüleme, bilgisayarlı tomografi (BT), sayisal meme tomosentezi (DBT), manyetik rezonans görüntüleme (MRI), nükleer görüntüleme (PET-SPECT), ultrasonografi, elektriksel empedans tomografisi (EIT) ve termal kızılötesi görüntüleme (IRT) sistemleriyle elde edilmektedir. Bu biyomedikal görüntüleme sistemleriyle vücut içerisindeki çeşitli dokuların ve organların anatomik ya da fizyolojik görüntüsünü non-invaziv yöntemle elde etmek mümkün hale gelmiştir. Teknolojideki hızlı ilerlemeler, görüntülemenin tıpta tanı ve tedavi amaçlı aktif olarak kullanımını sağlamış ve biyomedikal görüntüleme sistemleri tıp dünyasının vazgeçilmez bir parçası haline gelmiştir (Bercovich \& Javitt, 2018; Wolbarst \& Hendee, 2006). Bu makalede, klinikte kullanılan ileri biyomedikal görüntüleme teknolojilerinin gelişimi, mevcut yetenekleri ve uygulama alanları hakkında genel bir derleme sunulmuş ve bu derleme, görüntüleme sistemleri üzerinde çalışacak araştırmacılara temel bilgi niteliğinde kaynak olarak önerilmiştir.

\section{2. İleri Biyomedikal Görüntüleme Tekniklerinin Karakteristikleri}

Görüntüleme hastalığın tespitinde, teşhisinde, evrelendirilmesinde, tedavi planlamasında ve tedavi yanıtının izlenmesinde büyük bir rol oynamaktadır. Görüntülemede, yap1 ve morfolojiye odaklanmış geleneksel "anatomik merkezli" yaklaşım kullanılmaktadır. Teknolojinin ilerlemesine paralel olarak bu yaklaşım aynı zamanda, işlevsel ve moleküler görüntüleme yoluyla vücuttaki biyolojik süreçlerin görselleştirilmesine de dönüşmüştür (Dunne vd., 2017). Ayrıca, tıbbi görüntüleme için geliştirilen tekniklerin çoğunun bilimsel ve endüstriyel uygulamaları da bulunmaktadır (Ganguly vd., 2010). Bu durum, tüm tıbbi görüntüleme yöntemlerinin kullanım alanlarının genişlemesine ve daha da geliştirilmesine yol açmıştır (Erturk vd., 2009). Bu bölümde tıbbi görüntüleme yöntemleri ve klinik uygulamaları hakkında genel bir bilgilendirme sunulmuştur.

\subsection{Röntgen (X-ray) Görüntüleme}

$\mathrm{X}$-ray görüntüleme, en yaygın ve bilinen tıbbi görüntüleme tekniğidir. Wilhelm Conrad Röntgen tarafından 1895'te X-ışının bulunması ile X-ray görüntüleme başlamıştır. Röntgen yaptığ 1 deneylerde katot 1 şın tüplerine elektrik akımı uygulamış ve bu esnada tesadüfen baryum tuzuyla kaplı bir ekranda 1ş11tı oluştuğunu fark etmiştir. Bu tür 1şıltılara neden olan ışınların kaynağını çözemeyen Röntgen, o zamana kadar tanımlanmamış bir ışın türü olması nedeniyle bu ışınlara "bilinmeyen" anlamına gelen 'X-1şınları' adını vermiştir. Röntgen bu keşfinden kısa bir süre sonra, bir insanın ilk radyografisini (Şekil-1) olan, eşinin yüzüklü elini görüntülemeyi başarmıştır (Gunderman, 2012).

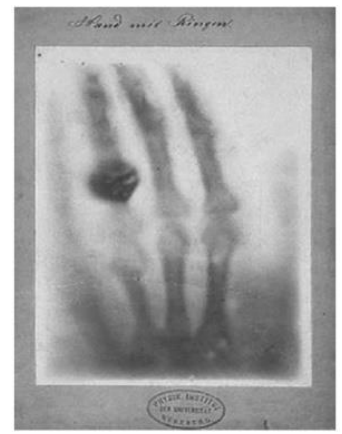

Şekil 1: Insana ait ilk radyografi, Bayan Röntgen 'in yüzüklü elinin bir görüntüsü (Gunderman, 2012).

X-1şınları, ultraviyole ve görünür 1şık spektrumundan daha küçük dalga boylarına ve daha yüksek frekansa sahip elektromanyetik spektrumun bir parçasıdır. X-1şınları $10 \mathrm{pm}$ ile $10 \mathrm{~nm}$ arasında değişen dalga boyuna sahip olup boşlukta $300.000 \mathrm{~km} / \mathrm{s}$ 1şık hızı ile hareket etmektedir. Küçük dalga boyları nedeniyle, X-ışınları insan vücudunda ükemmel düz penetrasyon ve iletim kapasitesi sağlayan yüksek enerjiye sahiptir (Dhawan, 2011; Jensen \& Wilhjelm, 2006). X-1şınları 1897 yılında Osmanlı İmparatorluğunda tıpta ilk defa Esad Feyzi Bey tarafından hastanın sağ bileğindeki şarapnel parçasının yerini tespit etmek için kullanılmıştır (Ülman \& Olay, 2006).

X-ray görüntülemenin temeli, dokuların X-1şınını farklı derecede soğurmasına dayanmaktadır. Örneğin kemik dokunun, X-ışınlarını yumuşak dokudan daha fazla soğurması sayesinde, röntgen görüntülemede dokular birbirinden ayırt edilebilmektedir. Kaynaktan üretilen X-ışınları şekil 2-a' da gösterildiği gibi hastaya yönlendirilir. Hastanın vücudundan geçen X-1şınları hastanın hemen altında bulunan detektöre düşürülerek kaydedilir. Görüntü elde edilirken görüntü kontrastını artırmak için dağınık X-ışınlarının etkisini azaltmak gerekir. Bu problemi çözmek için dedektörün önüne şekil 2-b' de gösterilen 1zgara yerleştirilir. Dedektöre kaydedilen X-1şınları önce 1şı̆̆a, daha sonra voltaja dönüştürülür ve en sonunda dijitalleştirilir. Şekil 2-c' deki akciğer röntgen görüntüsünde kaburga alanındaki açık gri renkli bölümler sert dokuları yani kemikleri temsil ederken koyu gri renkli bölümler ise akciğerin yumuşak dokularını temsil etmektedir. Bunun nedeni yumuşak 
dokuların X-ışınını daha fazla, sert dokuların ise X-ışınını daha az absorbe etmesinden kaynaklanmaktadır (Dhawan, 2011; Smith \& Webb, 2010).
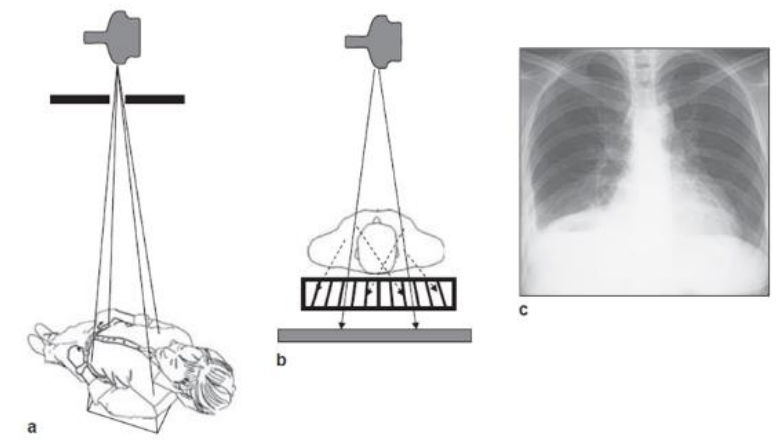

Şekil 2: a) Düzlemsel radyografi kurulumu. Tüpten gelen X-ışını hüzmesi toplanır, hastadan geçer ve hastanın altına yerleştirilen dijital dedektör üzerinde bir görüntü oluşturulur. (b) Görüntü kontrastını arttırmak için dağınık Xıșınlarından gelen katkıyı azaltmak için doğrudan dedektörün önüne bir saçılma önleyici ızgara yerleştirilir. (c) Gögüste düzlemsel bir radyografi örneği. Kemikler, X-ışınlarını akciğerlerin yumuşak dokusundan çok daha büyük bir dereceye kadar zayıflatır ve görüntüde parlak görünür (Smith \& Webb, 2010).

X-ray görüntüleme göğüs hastalığının tanı ve tedavisinde (Gleeson, 2008), kardiyak hastalarda önemli bir başlangıç tanı aracı olarak (Scott \& Messer, 2018), plevral anormallik varlığının tespitinde (Qureshi \& Gleeson, 2006), kemik yapısının araştırılmasında (Moghaddam vd., 2008), yapısal eklem hasarının değerlendirilmesinde (Ørnbjerg \& Østergaard, 2020), kalça bozukluklarının değerlendirmesinde (Mourad vd., 2019), atletik el yaralanmalarının teşhisinde (Sundaram vd., 2013) kullanılmaktadır. Ayrıca yumuşak ve sert doku lezyonlarının sinıflandırmasında da kullanılmaktadır (Miwa \& Otsuka, 2017). Şekil 3'te X-ray görüntüleme ile sınıflandırılan kemik lezyonları gösterilmiştir.
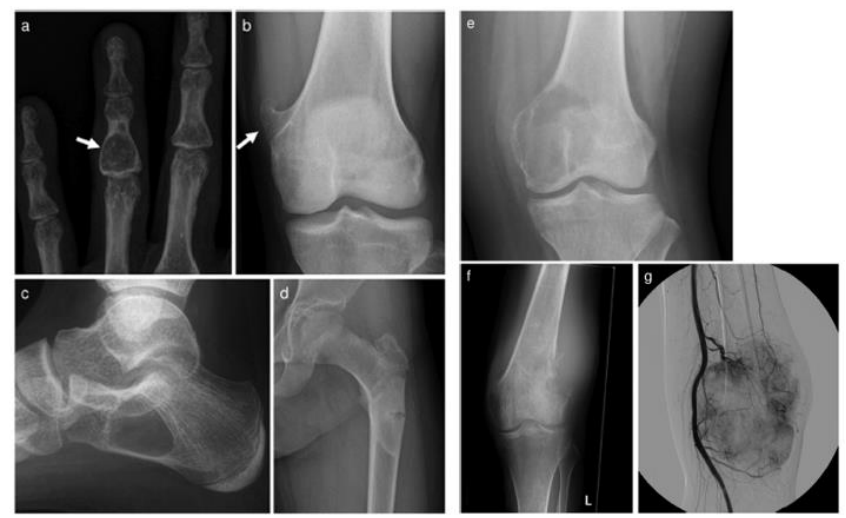

Şekil 3: X-ışını görüntüleri. (a). Enkondrom. (b). Osteokondrom. (c). Basit kemik kisti. (d). Lifli displazi. (e). Dev hücreli tümör. (f). Osteosarkom. (g). Osteosarkom (anjiyogram) (Miwa \& Otsuka, 2017).

X-ray görüntülemenin farklı uygulama alanları arasında mamografi ve floroskopi yer almaktadır. Floroskopi, X-ışını görüntüsünün gerçek zamanlı olarak monitöre yansıtıldığı bir tıbbi görüntüleme türüdür. Floroskopi uygulması esnasında hastaya X-1şını yayan kontrast bir madde verilir ve bu maddenin vücuttan geçişi izlenmektedir (Wang vd., 2006). Mamografi ise, düşük dozda X-1şını kullanarak memenin içyapısını görüntüleyen ve meme kanserindeki küçük kitleleri dahi erken aşamalarda tespit edilebilen bir görüntüleme yöntemidir (Hogg vd., 2015).

\subsection{Bilgisayar Tomografi (BT)}

Düzlemsel röntgen görüntülemede (X-ray), görüntülenmesi istenen vücut bölgesinin görüntüsü tek bir projeksiyon olarak elde edilmektedir. $\mathrm{Bu}$ durum, üst üste binen dokuların tek bir projeksiyonda anlaşılabilir bir şekilde görüntülenmesini sınırlamaktadır. Bu sorunu çözmek için farklı açılardan alınmış birkaç projeksiyonun görüntü geri çatma algoritmalarıyla işlenmesi sonucu, yapıların dilimler (slice) halinde görüntülenmesini sağlayan teknolojiler geliştirilmiştir. Dilim görüntüleme teknikleri kullanılarak, morfolojik özelliklerin katman katman ayırt edilebilir şekilde görüntülenmesi ve hayati derecede önemli bilgilerin çıkarılması mümkün olmaktadır. Bu tekniklerden biri olan BT'nin radyolojide kullanımı yeni bir çı̆̆ır açmıştır. BT ilkeleri ilk olarak Sir Godfrey Hounsfield ve Allan Cormack tarafından 1972 'de tanımlanmış ve İngiltere'de geliştirilmiştir. Hounsfield ve Cormack bu buluşları ile 1979 yılında tıp alanında Nobel ödülünü almışlardır (Mikla \& Mikla, 2013). Avusturyalı bir matematikçi olan Johann Radon, BT'de görüntü geriçatma için kullanılan ve Radon dönüşümü olarak adlandırılan teorik temelleri 1917'de yayınlamıştır (Radon, 2005). 1973 yılında ilk kez ABD'de Mayo Klinikte BT ünitesi kurulmuştur. BT cihazı, ülkemizde ise ilk olarak Hacettepe Üniversitesi'nde Mart 1976'da kullanılmaya başlamıştır (Ertürk, 2005).

BT görüntülemenin arkasındaki temel ilke, hastanın çevresinde tam bir dairesel taramayla farklı açılardan alınan iki boyutlu X-1şını projeksiyonlarını kullanılarak görüntü geri çatma algoritmalarıyla kesitsel görüntüleme yapabilmesine dayanmaktadır. Bir BT'nin temel üç bileşeni, düzlemsel röntgen görüntülemede olduğu gibi X-1şını tüpü, hasta ve bir dedektör sistemidir (Smith \& Webb, 2010). BT'nin fiziksel yapısının ve çalışma prensibinin farklı perspektiflerden sunulan görselleri şekil 4'te verilmiştir.

BT uygulaması esnasında hasta, dedektör ve X-1şını kaynağı arasına yerleştirilir. X-ışını kaynağı ve dedektör belirlenen açılarla sarmal bir tarama yolunu izleyerek hasta etrafında tam bir tur döndürülür. Hastadan alınan her projeksiyon görüntü geri çatma algoritmalarıyla işlenir ve kesitsel görüntü elde edilir. Düzlemsel röntgen görüntülemedeki dokuların üstüste binmesi nedeniyle detayların ayırt edilememesi problemi, BT'nin kesitsel görüntüleme prensibi sayesinde aşılmaktadır (Romans, 2018; Smith \& Webb, 2010).
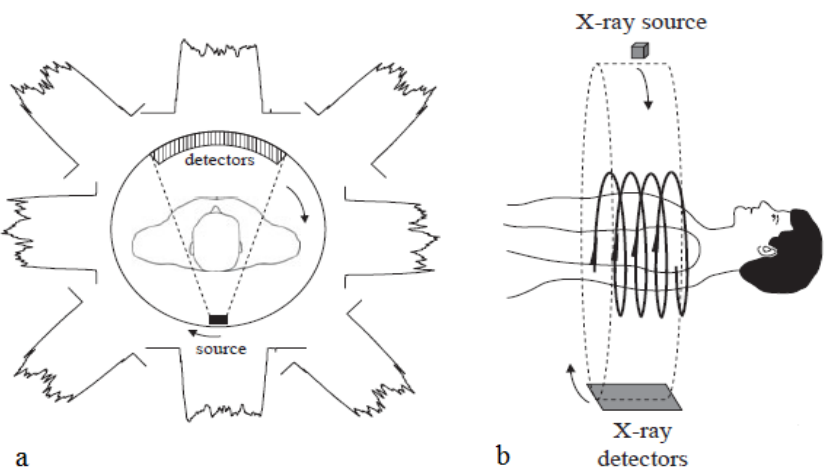

Şekil 4: Bilgisayarlı tomografinin çalışma prensibi. (a) Görüntüleme ilkesi bir dizi tek boyutlu projeksiyonu kaydetmek için X-ışını tüpünün ve çoklu dedektörlerin eşzamanll ve eşeksenli rotasyonuna dayanmaktadır. (b) Baş/ayak ekseni boyunca masa hareketi nedeniyle, X-ıșını demeti hasta etrafinda sarmal bir yol izlemektedir (Smith \& Webb, 2010). 


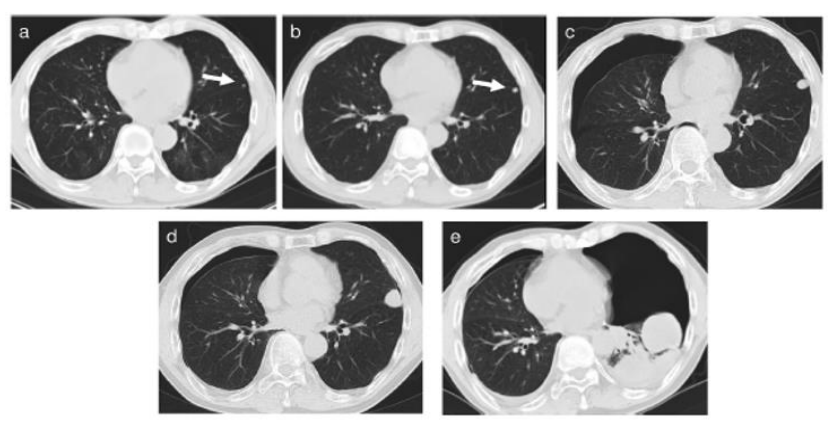

Şekil 5:Osteosarkomlu hastalarda akciğer metastazlarının zaman süreci. (a) metastatik akciğer nodülünün saptanmast, (b) 4. ay, (c) 8. ay, (d) 12. ay, (e) 16. ay (Miwa \& Otsuka, 2017).

BT görüntüleme düzlemsel röntgen görüntülemeyle kıyaslandığında dokuların X-1şını tutma kapasitelerinin direkt ölçülmesi sebebiyle röntgen görüntülemeden daha ayrıntılıdır (Romans, 2018; Smith \& Webb, 2010). Ölçümler, BT'nin geliştirilmesinde öncülerden biri olan Godfrey Hounsfield'in adını taşıyan Hounsfield birimlerinde (HU) ifade edilmektedir (Hounsfield, 1973).

Pankreastaki kistik tümörleri görüntülemede (Sidden \& Mortele, 2007), dental görüntüler ile yetişkinlerde yaş tahmini yapmada (Penaloza vd., 2016), el ve distal önkol kırıklarının teşhisinde (Pallaver \& Honigmann, 2019), akut kafa travmasının değerlendirilmesinde(Wei vd., 2010), kardiyak kitlelerin görüntülenmesinde (Young vd., 2019), lenf düğümleri, akciğer, pelvis, karaciğer, dalak, böbrekler (Samei, 2020), çene (Mah vd., 2010), kalp (Choi vd., 2020), omurga (W. Zhang vd., 2020) ve ekstremiteler (Miwa \& Otsuka, 2017) gibi neredeyse vücudun her yapısının incelenmesinde BT görüntüleme tekniği kullanılmaktadır. Ayrıca günümüz pandemisi ilan edilen COVID-19 hastalığının erken teşhisinde, BT görüntüleme tekniği doktorlara yardımcı olan tanı yöntemlerinin başında gelmektedir (Zhao vd., 2020). COVID-19 tespiti için yapılan öncül RT-PCR (reverse-transcription polymerase chain reaction) testlerinden daha hassas sonuçlar vermesi nedeniyle göğüs BT'si COVID-19 tanısında tercih edilmektedir (Ai vd., 2020). BT, tümörün anatomik yerleşimi ve çevresindeki yapılara tutulumu hakkında yapısal bilgiler sağlamaktadır. Yüksek çözünürlüklü kesitsel BT görüntülerinde anormal lezyonlar 3 mm'den büyükse saptanabilmektedir. Şekil 5-a'da metastatik akciğer nodülünün saptanması gösterilmiştir. Şekil 5-b-c-d-e sırası ile nodülün 4., 8., 12. ve 16. aylardaki durumunu göstermektedir (Miwa \& Otsuka, 2017).

Bir BT taraması ile hastaya verilen radyasyon dozu, düzlemsel bir radyografi ile verilen radyasyon dozundan 100 ile 1000 kat daha fazla olduğu kabul edilmektedir. Bu durum, BT taramasında maruz kalınan radyasyon kaynaklı DNA yaralanmalarına ve böylece kanser riskinin artmasına neden olmaktadır. BT taraması, cerrahi planlamanın yapılması, iyi (benign) ve kötü (malign) huylu tümör arasındaki farklılaşmanın ve tekrarlayan metastatik hastalığın saptanması gibi kritik durumlarda, yüksek radyasyon riskine rağmen önerilmektedir (Miwa \& Otsuka, 2017; Semelka \& Elias, 2013).

BT ilk üretildiği günden bu yana tarama hızı, hasta konforu ve çözünürlük konularında büyük gelişmeler kaydetmiştir. Tarama sürelerinin hızlanması, daha fazla anatominin taranmasina, solunum veya peristalsis gibi hasta hareketinden kaynaklanan gürültülerin ortadan kaldırılmasına yardımcı olmaktadır. Günümüzde, BT görüntülemede mümkün olan en düşük X-ışını dozu ile mükemmel görüntü kalitesi sağlamak ve e-ISSN: 2148-2683 böylece daha güvenilir bir tanı koymak için çok yönlü araştırma ve geliştirme yapılmıştır ve yapılmaya devam etmektedir (Mikla \& Mikla, 2013).

\subsection{Sayısal Meme Tomosentezi (DBT)}

Mamografi, erken evre meme kanserinin tespiti için etkili bir görüntüleme aracıdır. Fakat mamografi yardımı ile elde edilen 2-boyutlu (2B) görüntülerde üst üste binen dokunun ortaya çıkması, meme dokusunda oluşan kanserli yapıyı yorumlamanın önünde önemli bir engel oluşturmaktadır. Meme tomosentezi, sınırlı açılardan alınan birkaç projeksiyonun geri çatılması prensibi sayesinde, doku örtüşmesi problemini azaltmak veya ortadan kaldırmak için kullanılan yenilikçi bir 3boyutlu (3B) görüntüleme yöntemidir (Tagliafico vd., 2016). Sayısal meme tomosentezinin (Digital Breast Tomosynthesis: DBT) klinikte uygulanabilirliği, dijital mamografi sistemlerinin piyasaya sürüldüğü 1990'ların sonunda kanıtlanmıştır (Niklason vd., 1997). DBT sistemi; statik bir dedektör, meme dokusunu sıkıştırmak için kullanılan iki plaka ve bir yay kolda hareket eden X-1şını kaynağı olmak üzere üç ana kısımdan oluşmaktadır. Şekil 6'da örnek olarak bir DBT geometrisi gösterilmiştir. DBT geometrisinde tanımlanan uzaklıklar üretici firmaya göre farklılık göstermektedir (Polat \& Yildirim, 2018). DBT görüntüleme tekniğinde, $\mathrm{X}$-1şını tüpü sınırlı bir açı aralığında döndürülürken sabit bir dijital detektör ile elde edilen düşük dozlu sınırlı sayıda projeksiyon görüntüsü kullanılarak, geri çatma algoritmaları ile memenin görüntüleri dilimler halinde $3 \mathrm{~B}$ olarak elde edilmektedir. Mamografiden elde edilen geleneksel mamogramlara kıyasla, DBT görüntüleri, meme dokusunun hedef kesitindeki yapıların daha iyi görünmesini sağlarken, diğer kesitlerdeki yapıların kontrastını azaltmaktadır (Tagliafico vd., 2016).

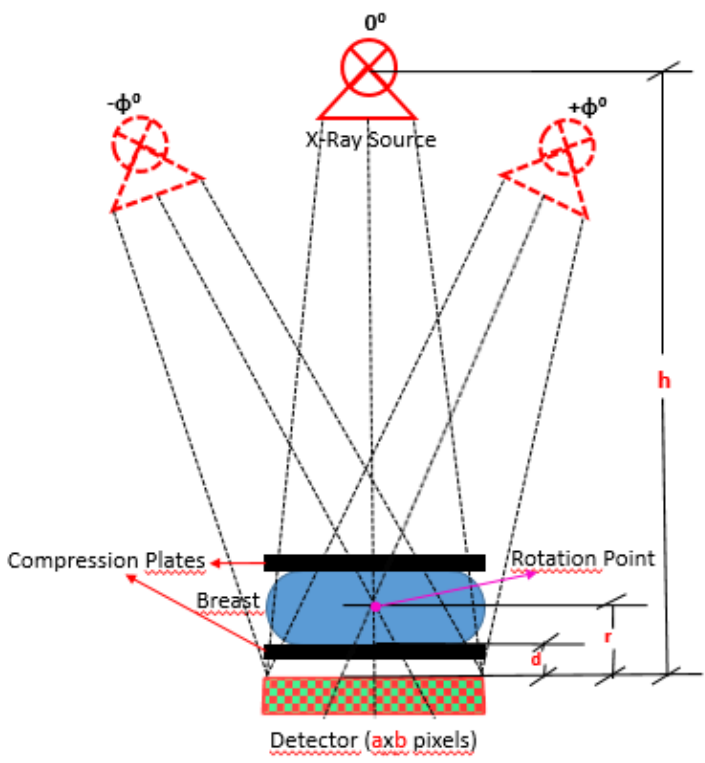

Şekil 6: DBT sisteminin geometerisi. X-ışın kaynă̆ $-\phi^{o}$ ve $\phi^{o}$ açıları arasında döndürülmektedir. Dedektör boyutu $a * b$ piksel şeklinde tanımlanmıştır. Detektörden ıkıştırma plakasına, kaynağın dönüş noktasına ve X-ışın kaynağına olan uzaklıklar sirasiyla $d, r$ ve h'dir. dedektör boyutu $a^{*} b$ piksel şeklinde tanımlanmıştır (Polat \& Yildirim, 2018).

DBT’nin açısal tarama özelliği ile lezyonların 3B görüntülenmesi sayesinde, cerrahi planlama için tümörün meme içinde yerleştiği lokalizasyonun tespiti mümkün olmaktadır. DBT'de 3B görüntü oluşturmak amacıyla alınan birkaç projeksiyon için uygulanan toplam radyasyon dozu, 
mamografide tek çekim projeksiyon için uygulanan radyasyon dozundan daha azdır. Birçok hasta tarama esnasında memenin sıkıştırılmasından kaynaklanan acı nedeniyle mamografiden kaçınmaktadır. DBT görüntülemede, mamografide yapıldığı gibi meme dokusunun dedektöre daha fazla yayılması için plakaların çok fazla sıkıştırılmasına gerek olmadığından hastalar daha az acıya maruz birakılmaktadır (J. M. Park vd., 2007). Daha az radyasyon, daha az acı ve 3B lokalizasyon gibi birçok yararı sayesinde DBT görüntüleme sistemlerinin, 2011 yılında Amerika Birleşik Devletleri'nde Food and Drug Administration (FDA) onayı alındıktan sonra klinikte uygulanması hızla yaygınlaşmıştır (Friedewald, 2017). Şekil 7'de sağ memede ele gelecek kadar büyük nodülü olan 59 yaşında bir kadın hastanın mamogram ve tomosentez görüntüsü gösterilmiştir. Mamogramda görünmeyen dördüncü kitle tomosentezin bir kesit görüntüsünde orataya çıkmıştır.

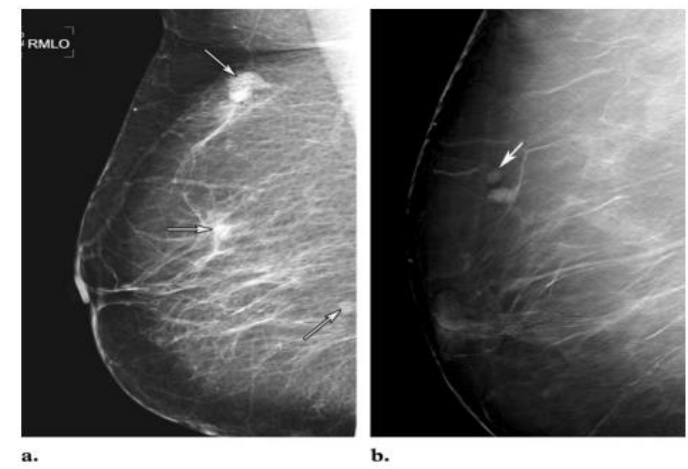

Şekil 7: (a) Dijital mamogram üç ana kütleyi (oklar) gösterir, (b) Meme tomosentezi görüntüsü, üç kütlenin sinırlart ve dördüncü kütleyi gösterir (ok) [45].

\subsection{Manyetik Rezonans Görüntüleme (MRI)}

Manyetik rezonans görüntüleme (magnetic resonance imaging: MRI), hem klinik tıpta hem de biyomedikal araştırmalarda kanıtlanmış sonuçlarla 1980'lerin başında tanıtılmasından bu yana gelişen karmaşık bir görüntüleme tekniğidir. Raymond Damadian önce 1971 'de fareler üzerinde, sonra 1974'te ise insanlar üzerinde yaptığı deneyler sonucunda fare ve insana ait dokuların ve tümörlerin nükleer manyetik gevşeme sürelerinin farklı olduğunu göstermiştir. $\mathrm{Bu}$ da bilim insanlarını hastalıkların araştırılmasında manyetik rezonans (MR) görüntüleme tekniğini kullanmaya teşvik etmiştir (Damadian, 1971; Damadian vd., 1974). Bir yıl sonra, oluşturulan bir fantomun ilk MR görüntüsü, Paul Lauterbur tarafından manyetik gradyan kullanılarak üretilmiştir (Lauterbur, 1973). İnsan vücuduna ait ilk MR görüntüsü (parmak) 1976 yılında Peter Mansfield ve meslektaşları tarafindan yayınlanmıştır (Mansfield \& Maudsley, 1977). Beynin ilk MR görüntüsü, 1980 yılında Nottingham'da elde edilmiştir (Hawkes vd., 1980). Peter Mansfield ile Paul Lauterbur MR görüntülemedeki önemli katkılarından dolayı 2003 yılında Nobel tıp ödülünü almışlardır. Fakat bu iki bilim insanı MR görüntülemenin ilerlemesini sağlayan çalışmalarını birbirlerinden bağımsız olarak yapmışlardır (Smith \& Webb, 2010).

Manyetik alanı genellikle 0,5 ile 7 Tesla arasında olan MR sistemlerinde manyetik alan süper iletken mıknatıslar tarafindan üretilirken, helyum ile soğutulmaktadır. MR görüntüleme, farklı dokulardaki hidrojen $(\mathrm{H})$ çekirdeklerinin mekânsal haritasının çıkartılması prensibine dayanmaktadır. Yani görüntülemede kullanılan veri kaynağı hücrelerde bulunan $\mathrm{H}$ atomudur. Görüntü yoğunluğu herhangi bir uzamsal konumdaki $\mathrm{H}$ çekirdeklerinin e-ISSN: 2148-2683 proton sayısına bağlı olduğu gibi, dokuların viskozite, sertlik ve protein yapısına da bağlıdır. MRI sistemi üç ana donanım bileşeninden oluşmaktadır; bunlar sırası ile bir süper iletken mıknatıs, üç manyetik alan gradyan bobini ( $x-y-z$ yönlü) seti ve bir radyo frekans vericisi ve alıcısıdır (Şekil-8 a, b). Bu süper iletken mıknatısın manyetik alanı genel olarak 3 Tesla'dır, bu da dünyanın manyetik alanından yaklaşık olarak 60.000 kat daha fazladır. MR cihazının görüntülemede kullandığı enerji radyo dalgalarıdır. Radyo-frekans (RF) olarak isimlendirilen bu enerji elektromanyetik spektrum içerisinde yer alır (M. A. Brown \& Semelka, 2011; Smith \& Webb, 2010).
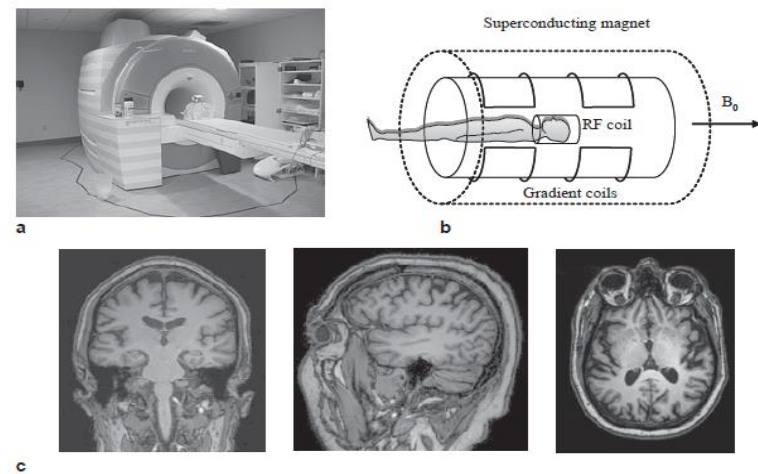

Şekil 8: Klinik MRI cihazı (a). Yatay yönde güçlü bir manyetik alan (B0) üreten süper iletken mıknatıs dâhil olmak üzere bir MRI sisteminin üç ana bileşeni (b), Beynin MR görüntüleri sirasıyla koronal, sagital ve aksiyal düzlemler (c) (Smith \& Webb, 2010).

MR görüntülemenin ilk aşamasında, normalde RF enerjisine duyarsız olan insan vücudu güçlü bir manyetik alana maruz bırakılarak RF dalgasına duyarlı hale getirilir. $\mathrm{Bu}$ güçlü manyetik alan vücutta bulunan $\mathrm{H}$ atomlarının hizalanmasına neden olur. Kesit görüntüsü alınacak bölgeye RF dalgası gönderilir ve bu enerjiyi alan $\mathrm{H}$ atomları, aldıkları enerji miktarına göre hizalandıkları konumlarından saparlar. RF enerjisi kesildiğinde $\mathrm{H}$ atomlarının eski konumlarına geri dönme sürecinde yaydıkları RF dalgaları, alıcı tarafindan toplanarak bilgisayarda görüntü oluştulur. Farklı protonlar, protonun bulunduğu dokuya bağlı olarak farklı sinyaller gönderdiğinden MR görüntülerinde gri tonların oluşmasına neden olmaktadır. Bu gri tonların anlamı incelemenin türüne göre değişmekle beraber, genel olarak beyaz-açık tonlar alınan sinyalin fazla olduğunu, koyu-siyah alanlar ise alınan sinyalin az olduğunu göstermektedir. MR görüntüleme yumuşak doku kontrast çözümleme gücü en yüksek radyolojik görüntüleme yöntemi olarak kabul edilmektedir (M. A. Brown \& Semelka, 2011; Kasban vd., 2015; Mikla \& Mikla, 2013; Smith \& Webb, 2010).

MR görüntüleme, prostat kanseri için şüpheli alanları tespit etmek ve lokalize etmek için (Stabile vd., 2020), diş hekimliğinde temporomandibular eklem bozukluklarını teşhis etmek ve tümörlerin derecesini değerlendirmek için (Di Nardo vd., 2018), özofagus hastalıklarının tanı ve tedavisi için (Leandri vd., 2019), insan plasental fonksiyonunu in-vivo değerlendirmek için (Sørensen \& Sinding, 2020), hasta yenidoğanlarda beyin yaralanmalarının kesin doğasını ve derecesini değerlendirmek için (Wintermark, 2012), çeşitli jinekolojik kanserlerin görüntülenmesi için (Laifer-Narin vd., 2018), interstisyel akciğer hastalıklarını değerlendirmek için (Lonzetti vd., 2019), kalıtsal kalp hastalıklarının görüntülenmesi için (Dennis vd., 2019), radyoterapi tedavi planlaması için (Dirix vd., 2014) kullanılan, geniş uygulama yelpazesine sahip olan bir sistemtir. Şekil 9.ah'de sırasıyla osteosarkom adı verilen kötü huylu kemik tümörü, 
kondrosarkom adı verilen kötü huylu kemik tümörü, dev hücreli kemik tümörü, Schwannoma adı verilen tümör, lipom ve diferansiye liposarkom adı verilen tümörün $\mathrm{MR}$ görüntüsü gösterilmiştir (Miwa \& Otsuka, 2017).
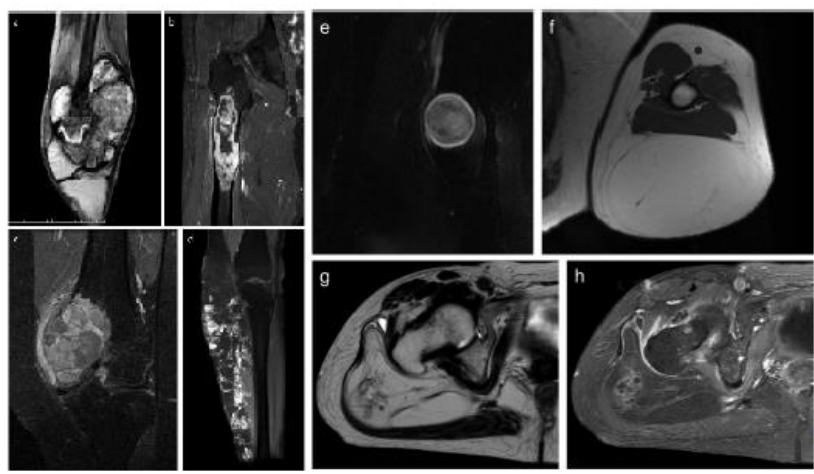

Şekil 9: Farkl MR tümörleri görüntüsü, (a)osteosarkom, (b) kondrosarkom, (c)dev hücreli kemik tümörü, (d) hemanjiyom, (e)Schwannoma, (f) lipom, (g) liposarkom, (h) iyi diferansiye liposarkom (Miwa \& Otsuka, 2017).

Bazı klinik taramalarda, çok küçük lezyonların saptanması gibi durumlarda kesin bir tanı için kontrastın çok düşük olduğu durumlarda, MR kontrast ajanlar sağlıklı ve hastalıklı doku arasındaki kontrastı artırmak için kullanılabilmektedir (Smith \& Webb, 2010). Şekil 10'da bu uygulamaya bir örnek gösterilmiştir (El Atta vd., 2016).
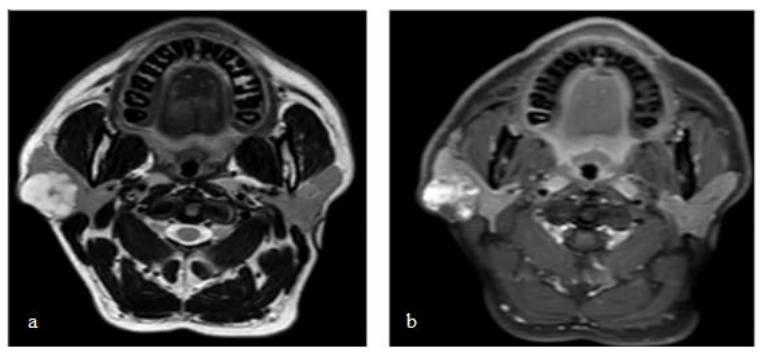

Şekil 10: a)Lezyonun iyi tanımlandığını gösteren eksenel T2 ağırlıklı MR görüntüsü,(b) Kontrast Sonrası lezyon heterojen artışını gösteren MR görüntüsü (El Atta vd., 2016).

\subsubsection{Fonksiyonel MR Görüntüleme (fMRI)}

Fonksiyonel MR görüntüleme (fMRI), beynin hangi alanlarının spesifik bilişsel görevlerde olduğunun yanı sıra konuşma, dil ve duyu hareketi gibi genel beyin işlevlerinin beynin neresinde yer aldığını belirlemek için kullanılan bir tekniktir. Beyin fonksiyonu çalışmalarında devrim yaratan fMRI metodunun temeli, beyindeki kanın oksijen seviyesine bağlı olarak MR sinyal yoğunluğunun değişmesine dayanmaktadır. Avantajlarının yanında fMRI'nın, doğrudan nöronal aktiviteyi ölçmek yerine nöronal aktiviteye bağlı perfüzyon ile ilişkili sinyalleri ölçtüğünden klinik ortamda bazı dezavantajları bulunmaktadır. $\mathrm{Bu}$ sebeple fMRI araştırma için yaygın olarak kullanılmasına rağmen, fMRI'nın klinik uygulamalardaki kullanımı sınırlıdır (Faro \& Mohamed, 2006; Jezzard vd., 2001). fMRI inme veya diğer nörovasküler olayları takiben hasta değerlendirmesinde (Mandeville vd., 2017), bilişsel bilimlerde yapı ve işlev arasındaki bağlantıyı anlamada (Bigler, 2014), özellikle öğrenme ve gelişim çalışmalarında (Rubia, 2013) ve cerrahi öncesi planlamalarda [69] kullanılmaktadır. Şekil 11'de sağlıklı bir denekten aynı anda alınan hem el hem de dil motor hareketlerinin bir fMRI haritasını gösterilmektedir (Gabriel vd., 2014).

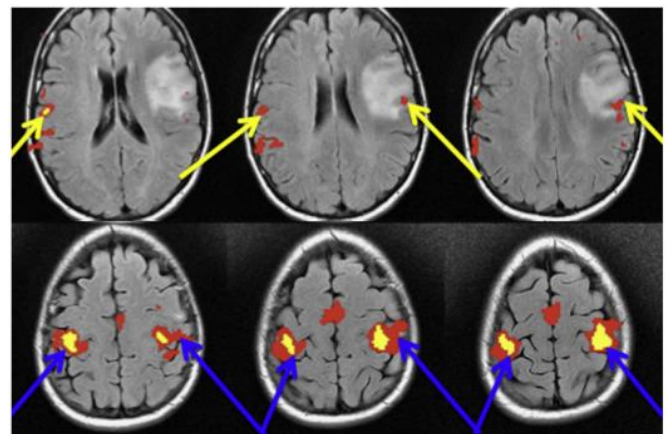

Şekil 11: Elin (mavi oklar) ve dilin (sart oklar) sinir sistemi cerrahisinde cerrahi planlama için kullanılan fMRI sinyallerindeki konumları gösterir (Gabriel vd., 2014).

\subsection{Nükleer Tıp}

Uranyumdan gelen radyasyonun emisyonu Antoine Henri Becquerel tarafından 1896'da keşfedilmiş ve 1936'dan beri çeşitli radyoaktif izotoplar nükleer tıpta kullanılmaktadır (Samei \& Peck, 2019). 1938'de insanlarda tiroid hastalıklarında Iodine $\left({ }^{131} \mathrm{I}\right)$ 'nin tanısal kullanımlarına ilișkin ilk makale yayınlanmıştır (Hertz vd., 1938). Bu disiplinin gelişimi bu uygulamadan sonra muazzam olmuştur ve hala ilerlemeye devam etmektedir. X-1şını görüntüleme, BT ve MR anatomik görüntüleme yöntemiyken, nükleer sintigrafi kemik döngüsü, sodyum-potasyum pompa aktivitesi ve mitokondriyal metabolizma gibi çeşitli metabolik aktiviteleri yansitan fonksiyonel bir görüntüleme yöntemidir. Nükleer tıp görüntüleme, fizyolojik ve/veya patofizyolojik süreçleri haritalamak üzere tasarlanan enjekte edilmiş veya absorbe edilmiş radyofarmasötiklerin izlenmesini içermektedir. $\mathrm{Bu}$ durumda radyofarmasötikler radyasyon yayıcı olarak tanımlanmaktadır. Radyofarmasötik izotoplar vücuda ağız yoluyla verildiğinde veya enjekte edildiğinde, radyoaktif madde kendini absorbe eden belirli organlara, kemiklere veya dokulara çekilir. Bir organ veya doku radyoaktif maddeyi emdiğinde insan vücudu, özel radyasyon dedektörleri tarafindan tespit edilebilen bir radyasyon üretir. Tarayıcı, hastadan gelen radyasyonları görüntüye dönüştürmek için bir bilgisayar ile çalışır. En yaygın kullanılan radyasyon izleyici Teknesyum ( $\left.{ }^{99 \mathrm{~m}} \mathrm{Tc}\right)$ 'dur ve yarılanma ömrü 6 saattir (Giussani, 2013; Mettler Jr \& Guiberteau, 2012; Samei \& Peck, 2019; Smith \& Webb, 2010). Nükleer tıp görüntüleme iki tekniği içerir; bunlar sırası ile SPECT ve PET görüntülemedir. PET ve SPECT görüntüleme nispeten düşük bir uzaysal çözünürlüğe sahip olmasına rağmen bu görüntüleme teknikerinin en büyük avantajı fizyolojideki çok küçük değişiklikleri dahi inceleme imkânı veren çok yüksek molar duyarlılıklarına sahip olmasıdır (Lecomte, 2009; Poeppel vd., 2009).

\subsubsection{SPECT (Tek Foton Emisyonlu Bilgisayarlı Tomografi) Görüntüleme}

En temel nükleer tıp görüntüleme tekniği olan SPECT görüntülemede, vücuda verilen radyoformasötik maddelerden tek doğrultuda yayılan gama fotonları, SPECT dedektörleri tarafindan tespit edilerek bilgisayar ünitesinde işlenerek kesitsel görüntünün oluşturulması prensibine dayanmaktadır (Cherry, 2004). Yayılan gama 1şınlarını tanımlayan ve dedektöre yönlendiren kolimatör, fotonlarla yüksek etkileşimi olan uygun bir malzemeden (kurşun veya tungsten) üretilmektedir. Hastadan gelen fotonlar kolimatör üzerindeki çok sayıda delik sayesinde detektöre iletilmektedir. Bu ışın iletimi, deliklere sadece paralel yönde gelen fotonların geçirilmesiyle gerçekleştirilmektedir ve 
bu yolla kolimatör gelen radyasyonun uzamsal haritasını tanımlamaktadır (Smith \& Webb, 2010).

İki ya da üç dedektör hastanın etrafında çeşitli açılar ile hareket ettirilerek bir dizi izdüşüm alınır. Bu izdüşümler çeşitli geri çatma algoritmalarıyla işlenerek vücut aktivite dağılımının dilim görüntüleri elde edilir (Giussani, 2013; Livieratos, 2012). Hassasiyeti arttırmak için bir gantriye (hastanın cihaz içine yerleştiği kısım) birden fazla gama kamerası monte edilebilir ve bu kameralar nesnenin etrafinda döndürülerek, kesitsel fonksiyonel görüntüler elde edilir (McVeigh, 2006). Astım hastalarının ventilasyonunu incelemede (Farrow \& King, 2019), araştırma amaçlı yeni ilaç çalışmalarında (Gomes vd., 2011), çeşitli kanser türlerinin görüntülenmesinde (Chua vd., 2009) ve Parkinson gibi nörodejeneratif hastalıkların tanısında ve hastalık gelişiminde (Gharibkandi \& Hosseinimehr, 2019) SPECT görüntüleme tekniği kullanılır. Şekil 12 (a)'da 3 dedektörlü bir gama kamera gösterilirken şekil 12 (b) 'de klinik uygulamalarda 2 dedektörlü kullanılan SPECT cihazı gösterilmiştir (Smith \& Webb, 2010).
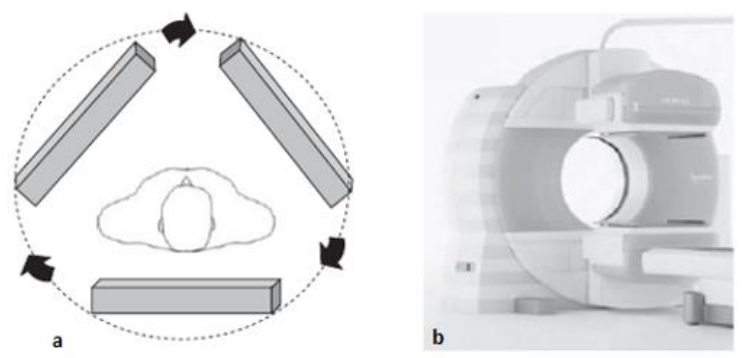

Şekil 12: (a) Gövde görüntüleme için üç kafalı dönen bir gama kamera SPECT sistemi, (b) 2 kafall SPECT kamera: kafalar beyni görüntülemek için içeri veya vücut için dışarl doğru hareket ettirilebilir (Smith \& Webb, 2010).

Anatomik detaylardan yoksun olmasına rağmen radyofarmasötiklerin metabolik yan ürünleri kan tarafindan emildiği için kemik iliği ve femoral damarlar SPECT görüntülerinde görülebilir (Lee vd., 2003). Bu duruma örnek olarak şekil 13'te pelvisin SPECT görüntüsü gösterilmektedir.

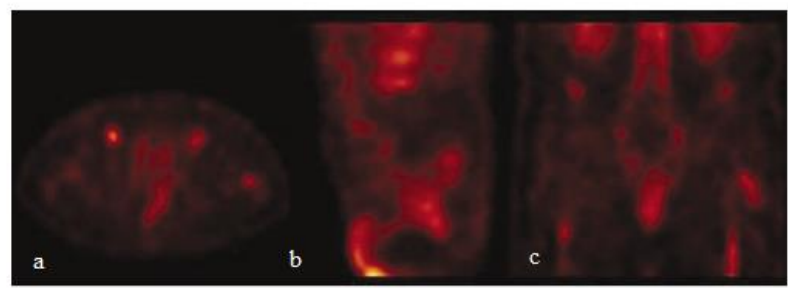

Şekil 13: Pelvisin (a) aksiyal, (b) sagittal, (c) koronal SPECT görüntüsü (Lee vd., 2003).

\subsubsection{PET (Pozitron Emisyon Tomografi) Görüntüleme}

Pozitron emisyon tomografisi (PET), bir hastalığın metabolizması hakkında bilgi sağlayan SPECT'e benzer bir yöntemdir. SPECT tekniğinde yayılan gama fotonları kolimatör ile tek doğrultuya yönlendirilip tespit edilirken, PET görüntüleme tekniğinde aynı anda, aynı yerde oluşan ve zit doğrultuda yayılan fotonlar tespit edilmektedir (Livieratos, 2012). Şekil 14'te iki karşıt dedektör tarafından anhilasyon fotonlarının tespitini gösteren PET tarayıcının şematik diyagramı gösterilmiştir. Hastaya, pozitron yayınımı yapan radyoizotoplar enjekte edilerek alınan PET tekniğindeki görüntüler SPECT cihazına göre çözünürlüğü daha iyi olan görüntülerdir (Giussani, 2013). PET biyolojik aktivitenin görüntülenmesini sağladığı için birçok hastalıkta anormal biyolojik aktiviteyi tanımlamada kullanılabilmektedir. Demans hastalığında beyin glikoz metabolizmasındaki bölgesel farklılıkların araştırılması, PET görüntüleme uygulamasına bir örnek olarak verilebilir (Noble \& Scarmeas, 2009).

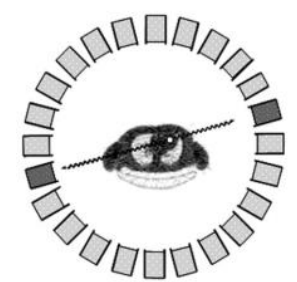

Şekil 14: İki karşıt dedektör tarafindan anhilasyon fotonlarının tespiti gösteren PET tarayıcının şematik diyagramı (Livieratos, 2012).

2000 yllında, PET ve BT kombinasyonu (PET-BT) klinik uygulamalarda kullanılmaya başlandıktan sonra bu teknikte muazzam gelişmeler meydana gelmiştir (Akhurst \& Chisin, 2000). PET-BT, kanser hücrelerindeki farklı biyokimyasal yolları görselleştirmemizi sağlayan moleküler bir görüntüleme yöntemidir. İki farklı cihazdan alınan bilgileri bir görüntü üzerinde birbiriyle ilişkilendirmek ve yorumlamak için üretilen özel görüntüler yüksek doğrulukta bilgiler vermektedir (Giussani, 2013). PET-BT görüntüleme tekniği, belirli patolojik lenfoma tiplerinde kemik iliği infiltrasyonunun saptanmasında (Xiao-Xue vd., 2019), Hodgkin lenfoma hastalığının evrelenmesinde (Zaucha vd., 2019), farklı metabolik kemik ve eklem hastalıklarının görüntülenmesinde (Beheshti, 2018), kasiskelet sistemi malignitelerinin tedavisinde (Kothekar vd., 2019), kardiyak cihaz enfeksiyonunun erken teşhisinde (W. Chen vd., 2018), özofagus kanserinin evrelenmesinde (Lu vd., 2016), torasik belirsiz bulguların doğasını karakterize etmede (Wachsmann \& Gerbaudo, 2014), meme kanserinin yeniden evrelenmesinde, tedaviye yanıtının değerlendirmesinde (Shamim vd., 2008) kullanılmaktadır.

Enflamatuar abdominal aort anevrizması hariç tutulduktan yedi ay önce eklenen enfekte aorto-iliak Dacron protezine neden olan Q-ateşine (Coxiella burnetii) sahip 58 yaşında erkek bir hastanın (a) BT görüntüsü, (b) PET görüntüsü, (c) PET-BT görüntüsü şekil 15 'te verilmiştir (Van der Vaart vd., 2008).
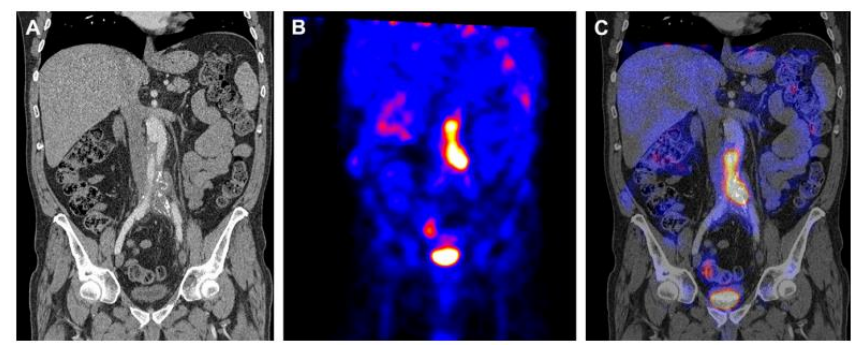

Şekil 15: Enfekte aorto-iliak Dacron protezine neden olan Q-ateşi (Coxiella burnetii) olan elli sekiz yaşında erkek hastaya ait (a)BT görüntüsü, (b) PET görüntüsü, (c) PET-BT görüntüsü (Van der Vaart vd., 2008).

\subsection{Ultrason Görüntüleme}

Görüntüleme yöntemi olarak ultrasonun potansiyeli, II. Dünya Savaşı sırasında geliştirilen sonar ve radar teknolojisini kullanarak, dünyadaki birçok araştırmacı grubunun ultrasonun teşhis yeteneklerini keşfetmeye başladığı 1940'ların sonlarında ortaya çıkmıştır. 1950'lerin başında, Minnesota'daki John Wild ve John Reid, prototip B mod ultrason görüntüleme cihazı geliştirmişlerdir (Shung, 2015). Bu teknik yarasalar, balinalar veya yunuslar tarafından kullanılan ekolokasyona yani ses ile 
yer belirlemeye benzer. Tüm standart klinik görüntüleme teknikleri içerisinde ultrasonografi hem en ucuz sistem hem de en rahat taşınabilir sistem olarak bilinmektedir. Aynı zamanda yan etkisi olmadan anlık görüntüleme alınmasını sağlamaktadır (Smith \& Webb, 2010). Ultrason, ilk kullanımından bu yana çarpıcı değişiklikler geçirmiş ve orijinal hantal B modu portal sisteminden, yüksek çözünürlüklü gerçek zamanlı görüntüleme sistemine dönüşmüştür (Harvey vd., 2002).

Ultrasonografi, megahertz (MHz) seviyesinde yüksek frekanslı geniş bant ses dalgaları kullanan bir tanı teknolojisidir. Tıbbi ultrason $30 \mathrm{kHz}$ ile $500 \mathrm{MHz}$ frekans aralığındadır. Genel olarak düşük frekanslar $(30 \mathrm{kHz}-3 \mathrm{MHz})$ terapötik amaçlar için, yüksek frekanslar $(2-40 \mathrm{MHz})$ görüntüleme ve Doppler ile tanıda ve çok yüksek frekanslar (50-500 MHz) mikroskobik görüntülemede kullanılmaktadır (Lemoigne vd., 2007). Görüntü üretmek için kullanılan ultrasonik dalgalar, genellikle 512'ye kadar bağımsız aktif kaynaktan oluşan tansdüser ile üretilmektedir (Smith \& Webb, 2010). Hasta bölgenin yakınında cildin karşısına yerleştirilen ultrason transdüseri hastaya ultrasonik dalga gönderir. Gönderilen bu dalga dokuların özelliklerine göre ya dokular tarafından emilir ya direkt yansıtılır ya da dalganın bir kısmı transdüsere zayıflamış bir şekilde döner. Kısacası farklı dokular, bu ultrasonik dalgaların ultrason cihazına farklı şekilde yansıtılmasına neden olur ve farklı görüntüler elde edilir (Lemoigne vd., 2007; Shung, 2015). Şekil 16 (a)'da ultrason görüntülemenin temel prensibi ve şekil 16 (b)'de ultrason görüntüsü verilmiştir. Transdüser dokuya bir dizi basınç dalgası gönderir. Doku arasındaki sınırlarda, enerjinin küçük bir kısmı transdüsere doğru geri dağılır. Doku ile ses hızını kullanarak, doku sınırının derinliği belirlenir. Şekil 16 (b)'de ise görüntüdeki her pikseldeki yoğunluk, o noktadan yansıyan ve algılanan sinyalin gücü ile orantılıdır (Smith \& Webb, 2010).
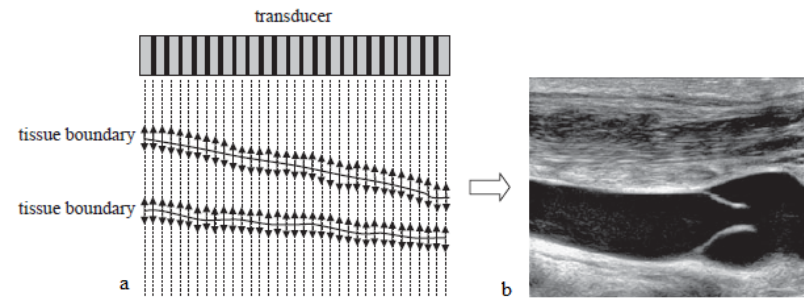

Şekil 16: (a) Ultrason görüntülemenin temel prensibi. Bir transdüser doku boyunca bir dizi basınç dalgası gönderir. Dokular arasındaki sinırlarda, enerjinin küçük bir kısmı tespit edildiği transdüsere geri saçılır. Doku boyunca ses hızı kullanılarak doku sınırının derinliği belirlenir. Işının örnek boyunca elektronik olarak yönlendirilmesi, görüntüyü oluşturan birbirini izleyen çizgiler oluşturur. (b) Görüntüdeki her pikselin yoğunluğu, o noktadan yansıyan ve algılanan sinyalin gücü ile orantılıdır (Smith \& Webb, 2010).

Ultrasonografi, tümörlerin büyüklüklerini ve karakterini değerlendirmek için uygun ve non-invaziv bir yöntem sunarken, aynı zamanda damarlar gibi çevredeki yapılar hakkında da bilgi vermektedir. Ultrasondan elde edilen gerçek zamanlı hareketli görüntüler, biyopsi prosedürlerini yönlendirmek için kullanılabilmektedir (Miwa \& Otsuka, 2017). İyonlaştırıcı radyasyon ya da güçlü manyetik alanların bulunmaması nedeniyle, ultrason özelikle jinekolojide çok geniş kullanım alanı bulmaktadır. Down sendromunun anne karnında tespiti (Arjunan \& Thomas, 2019) ve fetüsün ilk üç ayında merkezi sinir sistemi anormalliklerinin saptanması (N. Zhang vd., 2020) gibi uygulamalar ultrason görüntülemenin kullanım alanları arasında yer almaktadır. Şekil 17 (a)'da normal ense kalınlığına şekil 17 (b)' de ise anormal ense kalınlığına sahip fetüs görüntüleri gösterilmiştir (Arjunan \& Thomas, 2019).
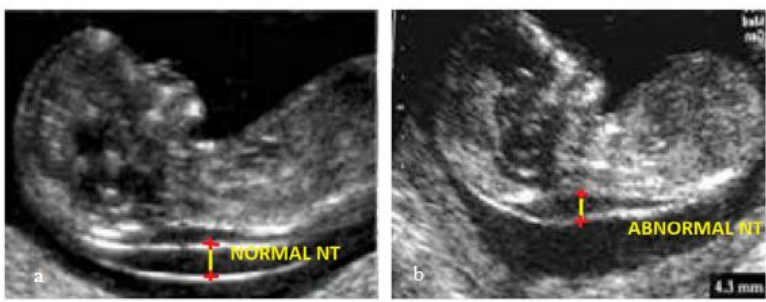

Şekil 17: a) normal ense kalınlı̆̆l, b) anormal ense kalınlı̆̆ına sahip fetüs (Arjunan \& Thomas, 2019).

Aynı zamanda ultrason görüntüleme teknikleri günümüzde, böbrek hastalığının tanı ve bakım sürecinde (Meola vd., 2016), tiroid nodüllerinin teşhis edilmesinde (Koundal vd., 2012), karaciğer lezyonlarının görüntülenmesinde (Virmani vd., 2014), memedeki anormal dokuların görüntülenmesinde (Jalalian vd., 2013), yumurtalık kistlerinin görüntülenmesinde (Acharya vd., 2013) ve birçok ortopedik yaralanmanın tespit edilmesinde (Simard, 2020) kullanılmaktadır.

\subsubsection{DOPPLER Ultrason}

Morfolojik ve yapısal bilgilere ek olarak ultrason, kan akışını gerçek zamanlı olarak ölçebilir ve belirli bir damardaki ayrıntılı kan haritalarını üretebilir (Szabo, 2004). Doppler ultrason, hareket ile frekans değişikliklerinin analizi yoluyla herhangi bir hareketin hızını belirlemektedir (Samei \& Peck, 2019). Biyomedikal alanda, bu fenomen, birçok teşhis uygulaması için ilgi çekici olan ultrason tabanlı kan akış hızı ölçümleri yapmak için kullanılmaktadır (Lemoigne vd., 2007). Doppler etkisi, bir kaynaktan yayılan ses frekansındaki bir değişikliğin bir gözlemci tarafindan, kaynak veya gözlemciden birinin hareketine veya her ikisinin de hareket ettiği duruma göre algilanması olgusu olarak tanımlanmaktadır (Shung, 2015). Kanın transdüsere doğru yaklaştığı durumda, alınan frekans gönderilen frekanstan daha yüksek, kanın transdüserden uzaklaştığı durumda ise daha düşük olmaktadır. İnvaziv olmayan kan akımı ölçümleri, bir takım patolojik koşullarda tanıda kritik bir bileşen olarak görülmektedir (Smith \& Webb, 2010). Renkli Doppler testisteki kan akışının azalmasının tespitinde (Sung vd., 2012), damar vaskülaritesinin ve damarlarda bulunan tümörlerin özelliklerinin değerlendirilmesinde (Miwa \& Otsuka, 2017), tekrarlayan tümörlerin erken saptanmasında (J.-J. Chen vd., 2013), dişi çevreleyen dokuların kan akışını ölçmede (Yoon vd., 2010), ses tellerinin morfolojisinin tanımlanmasında ve ses tellerinin titreşimli dokusundaki yer değiştirme hızının ölçülmesinde (Hsiao vd., 2001) kullanılmaktadır. Şekil 18'de tümörlü bir yapıya sahip olan testisin ultrason görüntüsü ve Doppler ultrason görüntüsü gösterilmiştir (McCarville, 2015).
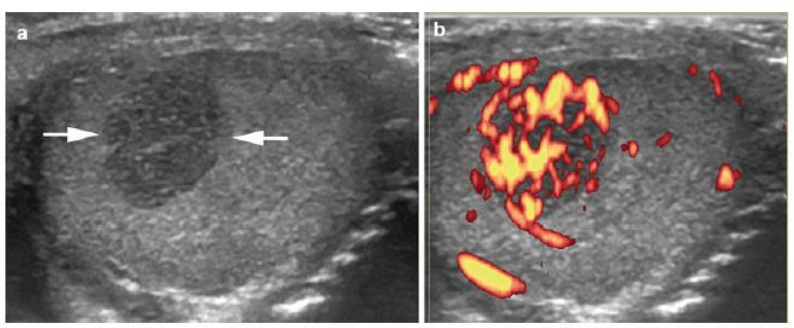

Şekil 18: (a) İyi tanımlanmış, küçük, katı, hipoekoik bir kütleyi ortaya çıkaran (oklar) testisin enine ultrason görüntüsü, (b) Testopüler Sertoli-Leydig hücre tümörü olan hastaya ait hipervasküler (turuncu yapılar) Doppler görüntüsü (McCarville, 2015). 


\subsection{Elektrik Empedansı Tomografisi (EIT)}

Elektriksel empedans tomografisinin (EIT) bildirilen ilk kullanımı, 1930'larda jeolojik bir çalışma olduğu belirtilmiştir (Stefanesco vd., 1930). Tıpta yeni kullanılmaya başlanan EIT, BT ve PET gibi tekniklerle karşılaştırıldığında yaklaşık bin kat daha ucuz, oldukça küçük ebatlara sahip ve iyonlaştırıcı radyasyon gerektirmeyen bir görüntüleme tekniğidir. EIT prensipte saniyede binlerce görüntü üretebilirken, kısıtlarının başında düşük uzamsal çözünürlüğe sahip olması gelmektedir (Bayford, 2006; Chitturi \& Farrukh, 2019).

İnsan vücudunun anatomisi ve dokuların sağlı̆̆ hakkında bilgi, dokunun elektriksel iletkenliğinin görüntülenmesiyle elde edilmektedir. Biyolojik doku empedans ölçümleri düşük $(20 \mathrm{~Hz})$ ile yüksek (1 $\mathrm{MHz})$ frekanslar aralığında yapılmaktadır (Bayford, 2006). Tablo 1'de farklı dokuların $10 \mathrm{kHz}$ 'deki elektriksel iletkenlikleri gösterilmiştir (Gray, 2002). EIT kullanılarak elde edilen ilk klinik görüntüler, direnç dağılımının tomografik görüntü haritalarını üretmek için insan vücudundaki çeşitli dokuların elektrik empedansını kullanan bir sistem geliştiren Sheffield grubu tarafindan üretilmiştir (B. H. Brown \& Seagar, 1987).

Tablo 1. 10kHz'deki sağlıkl dokuların elektriksel iletkenliği (B. H. Brown \& Seagar, 1987).

\begin{tabular}{|c|c|}
\hline Doku & $\begin{array}{c}\text { Elektriksel İletkenlik } \\
(\mathrm{mS} / \mathrm{cm})\end{array}$ \\
\hline $\begin{array}{c}\text { Beyin Omurilik } \\
\text { Slvlsl }\end{array}$ & 15.4 \\
\hline Kan & 6.7 \\
\hline Karaciğer & 2.8 \\
\hline Sinir Doku & 1.7 \\
\hline Gri madde & 3.5 \\
\hline Beyaz madde & 1.5 \\
\hline Akciğer & $\begin{array}{c}1.0 \text { (soluk verme), } \\
4.0 \text { (soluk alma) }\end{array}$ \\
\hline Kan & 6.7 \\
\hline Yă & 0.36 \\
\hline Kemik & 0.06 \\
\hline
\end{tabular}

EIT'de vücut yüzeyine yerleştirilen elektrotlardan çok sayıda empedans ölçümü yapılmaktadır. $\mathrm{Bu}$ ölçümler bir bilgisayar tarafından işlenerek görüntülenecek olan dokunun iki boyutlu görüntüleri üretilmektedir. Dokuların iletkenliklerindeki farklılıklar görüntüdeki gri tonları meydana getirmektedir (Bayford, 2006; Holder, 2004). EIT görüntülemenin, akciğerlerin ve pulmoner emboli ventilasyonunun görüntülenmesi, kan pıhtılarının saptanması (Nguyen vd., 2012), in vivo meme dokusunun 3 boyutlu tomografik görüntülerinin üretilmesi (Cherepenin vd., 2002), meme kanseri teşhisi (Zou \& Guo, 2003) ve epileptik aktivite sırasında empedans değişikliklerinin görüntülenmesi (Eadie vd., 2001) gibi çeşitli klinik uygulamaları bulunmaktadır. Şekil 19'da oksijen gereksinimi yüksek olan hastanın akciğerlerindeki bağıl bölgesel ventilasyon dağılımını gösteren EIT görüntüleri verilmiştir (Davies vd., 2019).
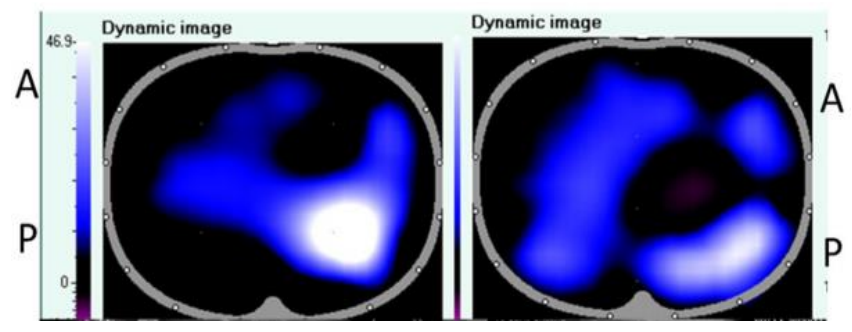

Şekil 19: Eşzamanl radyografilerle göğ̈̈s drenaj öncesi (solda) ve sonras (sağda) canlı empedans görüntüleri. Her alandaki empedans değişikliğini gösteren canlı tidal EIT görüntüleri, daha parlak (beyaz) pikseller, o bölgede artan ventilasyona eşdeğer daha büyük bir empedans değişikliğini göstermektedir (Davies vd., 2019).

\subsection{Kızılötesi Termal Görüntüleme (IRT)}

1800 yılında Sir William Herschel tarafından kızılötesi (IR) radyasyonun keşfinin ardından, sıcaklık ölçümü alanında çığır açan oğlu John Herschel tarafindan ilk termal görüntünün kaydı yapılmıştır (E. F. J. Ring, 2007). Hardy, 1934'te insan vücudundan gelen kızılötesi emisyonun fizyolojik rolünü tanımlamış (Hardy, 1934) ve tıp bilimlerinde kızılötesi termografi kullanımının önünü açan kızılötesi teknikle sıcaklık ölçümünün tanısal önemini belirlemiştir. $\mathrm{Bu}$ alanda kaliteli ekipman ve teknik bilgi birikiminin olmaması nedeniyle ilk kızılötesi termal görüntüleme (IRT) kullanımı ancak 1960 yılında yapılmıştır (F. Ring, 2010). Teknolojisi, çözünürlüğü, görüntü boyutu, kullanım kolaylığı ve taşınabilirliği konularındaki gelişmeleri sayesinde, artık klinik uygulamada tanınan ve noninvaziv görüntüleme yapan IRT'nin kullanımı yaygınlaşmıştır (Sousa vd., 2017). Kızılötesi termografi, sıcaklığını belirlemek için bir yüzey tarafından yayılan radyasyonun ölçülmesi kuralına göre çalışmaktadır. Kızılötesi görüntülemede, sıcaklık dağılımını görüntülemek için insan vücudundaki radyasyon, kızılötesi bir kamera ile vücuda temas etmeden algilanarak, yapısal bilgiler yerine fizyolojik aktivite hakkında bilgi vermektedir (Vollmer \& Möllmann, 2017). Tümör, oldukça vaskülarize bir yapı içerdiğinden arka plan dokusundan daha sıcak görünmektedir (Lahiri vd., 2012). Şekil 20'de meme kanserli bir hastanın sağ ve sol meme termogramı görüntüleri gösterilmiştir. Sağ meme termogramındaki çevrili bölge, çevredeki normal bölgelere göre daha yüksek sıcaklık göstermektedir. Daha sonra yapılan biyopsi să̆ memede kanserin varlığını doğrulamıştır (Lahiri vd., 2012).
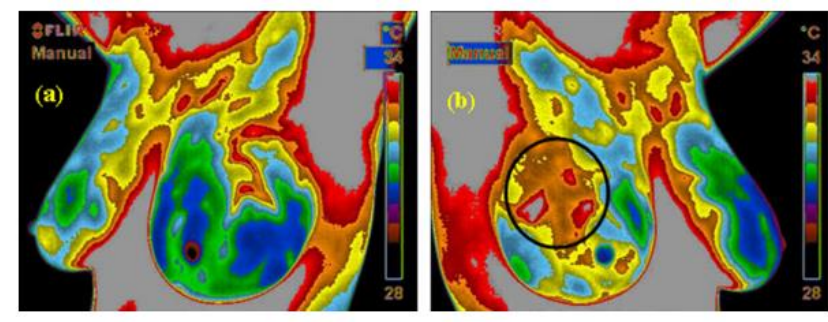

Şekil 20: Meme kanserli hastanın tipik termal görüntüleri, (a) sol meme termogramı ve (b) săg meme termogramı. Să̆ meme termogramındaki çevrili bölge, çevredeki normal bölgelere göre daha yüksek sicaklık gösterir. Daha sonra yapılan biyopsi sağ memede kanserin varlı̆̆ını doğrulamıştır (Lahiri vd., 2012).

Kızılötesi görüntülemenin tıp bilimindeki çeşitli uygulamaları meme kanseri tespiti (Kandlikar vd., 2017; Lozano III \& Hassanipour, 2019) diyabetik nöropati (Subramnaiam Bagavathiappan vd., 2010), vasküler bozukluk (S Bagavathiappan vd., 2009), beyin görüntüleme (termoensefaloskopi) (Shevelev, 1998), diş hekimliği (Fikackova \& Ekberg, 2004), kas ağrısı ve omuz sıkışma sendromunu 
görüntüleme (J.-Y. Park vd., 2007), romatolojik hastalıkların tanısı (Cherkas vd., 2003), kalp tedavisi (Manginas vd., 2010), kuru göz sendromu tanısı (Sniegowski vd., 2015) şeklinde sıralanabilir. $\mathrm{Bu}$ kullanım alanlarıan ek olarak profesyonel futbolcuarda meyadana gelen kas problemlerinin tespitinde ve iyileşme sürecinin gözlemlenmesinde deneysel olarak çalışmalar yapılmıştır (Ergene vd., 2020). Kızı̈ötesi termal görüntüleme yüksek duyarlılık ve özgüllük avantajı sağlarken, küçük tümör dokularının cilt yüzeyinde yeterli miktarda sıcaklık farkı oluşturamaması nedeniyle, daha küçük boyutlu kanserli dokuları daha derin yerlerden tespit edememektedir (Carlak vd., 2016).

\section{3. İleri Biyomedikal Görüntüleme Tekniklerinin Karşılaştırılması}

Makalede ileri biyomedikal görüntüleme teknikleri, görüntü kalitesi (mekansal çözünürlük ve kontrast), güvenlik (iyonize radyasyon etkisi ve 1sitma etkisi), radyasyonun vücuda etkisi ve sistem kullanılabilirliği (gerçek zamanlı bilgi ve maliyet) hakkında çeşitli parametreler üzerinden karşılaştırmalı bir şekilde incelenmiştir. İleri biyomedikal görüntüleme teknikleri mekanizma, hassasiyet, avantajlar, dezavantajlar ve kullanım alanları bakımından Tablo-2'de karşılaştırılmıştır.

Tablo 2: Farklı Biyomedikal Görüntüleme teknikleri arasındki karşılaştırma

\begin{tabular}{|c|c|c|c|c|c|}
\hline $\begin{array}{l}\text { Görüntüleme } \\
\text { Teknikleri }\end{array}$ & Mekanizma & Hassasiyet & Avantajlar & Dezavantajlar & $\begin{array}{c}\text { Kullanım } \\
\text { Alanları }\end{array}$ \\
\hline X-Ray & X-ray emisyonu & $1 \mathrm{~mm}$ & $\begin{array}{l}\text { Kolay kullanım, yüksek } \\
\text { detay, derine ulaşabilme }\end{array}$ & $\begin{array}{l}\text { Radyoaktif etki, düşük } \\
\text { kimyasal algılama }\end{array}$ & $\begin{array}{c}\text { Yumuşak dokular } \\
\text { ve sıvı }\end{array}$ \\
\hline BT & X-ray emisyonu & $0.5 \mathrm{~mm}$ & $\begin{array}{l}\text { Non-invaziv, hızlı ve } \\
\text { ağrısız, fiziksel } \\
\text { yoğunluktaki küçük } \\
\text { farklar ile ayırt edilir. }\end{array}$ & $\begin{array}{l}\text { Radyoaktif etki, gerçek } \\
\text { zamanlı bilgi yok, } \\
\text { yüksek maliyet }\end{array}$ & $\begin{array}{c}\text { Sert ve yumuşak } \\
\text { doku }\end{array}$ \\
\hline DBT & X-ray emisyonu & $1 \mathrm{~mm}$ & $\begin{array}{c}\text { Non-invaziv, kolay } \\
\text { kullanım, yoğun meme } \\
\text { dokusundaki tümörlerin } \\
\text { kolay tespiti }\end{array}$ & $\begin{array}{l}\text { Yüksek maliyet, } \\
\text { radyoaktif etki, yetersiz } \\
\text { nitelikli personel } \\
\text { eksikliği }\end{array}$ & Yumuşak doku \\
\hline MRI & $\begin{array}{c}\text { Proton } \\
\text { kutuplanmas1 ve } \\
\text { salınmas1 }\end{array}$ & $0.5 \mathrm{~mm}$ & $\begin{array}{l}\text { Kolay kullanım, derine } \\
\text { ulaşabilme }\end{array}$ & $\begin{array}{l}\text { Yüksek maliyet, uzun } \\
\text { görüntüleme süresi }\end{array}$ & $\begin{array}{l}\text { Sert ve yumuşak } \\
\text { doku }\end{array}$ \\
\hline $\mathrm{PET} / \mathrm{SPECT}$ & $\begin{array}{l}\text { Gamma 1şııı } \\
\text { emisyonu }\end{array}$ & $3 \mathrm{~mm}$ & $\begin{array}{l}\text { Kolay kullanım, derine } \\
\text { ulaşabilme, yüksek } \\
\text { moleküler hassasiyet }\end{array}$ & $\begin{array}{l}\text { Yüksek maliyet, düşük } \\
\text { detay, 1şımsal etiketleme }\end{array}$ & $\begin{array}{l}\text { Hücre } \\
\text { metabolizma, } \\
\text { hücre takibi }\end{array}$ \\
\hline US & Akustik dönüş & $1 \mathrm{~mm}$ & $\begin{array}{c}\text { Kolay kullanım, derine } \\
\text { ulaşabilme, yüksek hız, } \\
\text { gerçek zamanlı } \\
\text { görüntüleme, düşük } \\
\text { maliyet }\end{array}$ & $\begin{array}{l}\text { Düşük detay, düşük } \\
\text { kimyasal hassasiyet, }\end{array}$ & Yumuşak doku \\
\hline EIT & $\begin{array}{l}\text { Elektriksel } \\
\text { iletkenlik }\end{array}$ & $5-7 \mathrm{~mm}$ & $\begin{array}{c}\text { Non-invaziv, radyasyon } \\
\text { içermeyen, gerçek } \\
\text { zamanlı }\end{array}$ & $\begin{array}{c}\text { Düşük uzamsal } \\
\text { çözünürlük, elektrotların } \\
\text { yerleştirilme problemi }\end{array}$ & Yumuşak doku \\
\hline IRT & $\begin{array}{l}\text { Vücudun yaydığ } \\
\text { radyasyon. }\end{array}$ & $15 \mu \mathrm{m}$ & $\begin{array}{c}\text { Non-invaziv } \\
\text { iyonlaştırmayan } \\
\text { radyasyon, düşük } \\
\text { maliyetli }\end{array}$ & $\begin{array}{l}\text { Yetersiz uzamsal } \\
\text { çözünürlük, kötü } \\
\text { kalibrasyon sistemleri, } \\
\text { 1sitma etkisi fazla }\end{array}$ & Yumuşak doku \\
\hline
\end{tabular}




\section{Tartışma ve Sonuç}

İleri biyomedikal görüntüleme teknikleri, biyolojik sistemlerin karmaşıklığının çözülmesi ve anlaşılması, temel, cerrahi ve klinik tıp bilimlerine teknolojik katkılar sunarak sağlık hizmetlerinin iyileştirilmesi ve hastalık tanısı ve tedavisi için güçlü, yeni ve dikkate değer yetenekler sunmaktadır. İleri biyomedikal görüntülemedeki son gelişmeler sadece yap1 ve morfolojinin görüntülenmesine değil, hastalığın altında yatan bireysel biyolojik süreçlerin görselleştirilmesine de odaklanmıştır.

$\mathrm{Bu}$ çalışma birçok ileri biyomedikal görüntüleme teknikleri arasında karşılaştırmalı bir rapor sunarken, bu tekniklerin kavramları, çalışma prensipleri, teknolojik gelişim süreçleri, faydaları, riskleri ve uygulamaları ayrıntılarıyla sunulmuştur. $\mathrm{Bu}$ tekniklerden Röntgen (X-ray) görüntüleme (X-ray radyografisi), bilgisayarlı tomografi (BT), sayısal meme tomosentezi (DBT), manyetik rezonans görüntüleme (MRI), fonksiyonel manyetik rezonans görüntüleme (fMRI), tek foton emisyonlu bilgisayarlı tomografi (SPECT), pozitron emisyon tomografi (PET), ultrason görüntüleme, Doppler ultrason, elektrik empedansı tomografisi (EIT) ve kızılötesi termal görüntüleme (IRT) yöntemleri incelenmiştir.

Çeşitli parametrelerin ele alınarak karşılaştırmalı bir raporun sunulduğu bu derleme çalışmasında, farklı açılardan yapılan tartışmalar ve incelemeler, bu tekniklerin hiçbirinin, tıp alanlarının tümünde tek başına yeterli ve kesin sonuçlar veremeyeceğini göstermektedir. Ancak büyük oranda avantajlı, güçlü ve üstün oldukları kendi uygulama alanlarında, hastalık tanı ve tedavi noktasında göstermiş oldukları performanslar sayesinde, ileri biyomedikal görüntüleme teknikleri tıp ve sağlık dünyasının vazgeçilmez bir parçası haline gelmiştir.

Fizik ve matematik temel bilimlerinin kullanıldı̆̆ bilgisayar, elektronik ve yapay zekâ teknolojilerindeki başdöndürücü gelişmeler sayesinde, ileri biyomedikal görüntüleme tekniklerinde üstün yetenekler bakımından yeni bir döneme girileceği ve Ar-Ge faaliyetlerinin hız kesmeden devam edeceği açık olarak görülmektedir.

\section{Kaynakça}

Acharya, U. R., Saba, L., Molinari, F., Guerriero, S., \& Suri, J. S. (2013). Ovarian tumor characterization and classification using ultrasound: A new online paradigm. Içinde Ovarian neoplasm imaging (ss. 413-423). Springer.

Ai, T., Yang, Z., Hou, H., Zhan, C., Chen, C., Lv, W., Tao, Q., Sun, Z., \& Xia, L. (2020). Correlation of chest CT and RTPCR testing in coronavirus disease 2019 (COVID-19) in China: a report of 1014 cases. Radiology, 200642.

Akhurst, T., \& Chisin, R. (2000). Hybrid PET/CT machines: optimized PET machines for the new millennium? Journal of Nuclear Medicine, 41(5), 961-962.

Arjunan, S. P., \& Thomas, M. C. (2019). A Review of Ultrasound Imaging Techniques for the Detection of Down Syndrome. IRBM.

Assmus, A. (1995). Early history of X rays. Beam Line, 25(2), 10-24.

Bagavathiappan, S, Saravanan, T., Philip, J., Jayakumar, T., Raj,
B., Karunanithi, R., Panicker, T. M. R., Korath, M. P., \& Jagadeesan, K. (2009). Infrared thermal imaging for detection of peripheral vascular disorders. Journal of medical physics/Association of Medical Physicists of India, 34(1), 43.

Bagavathiappan, Subramnaiam, Philip, J., Jayakumar, T., Raj, B., Rao, P. N. S., Varalakshmi, M., \& Mohan, V. (2010). Correlation between plantar foot temperature and diabetic neuropathy: a case study by using an infrared thermal imaging technique. Journal of diabetes science and technology, 4(6), 1386-1392.

Bayford, R. H. (2006). Bioimpedance tomography (electrical impedance tomography). Annu. Rev. Biomed. Eng., 8, 6391.

Beheshti, M. (2018). 18F-Sodium Fluoride PET/CT and PET/MR Imaging of Bone and Joint Disorders. PET clinics, 13(4), 477-490.

Bercovich, E., \& Javitt, M. C. (2018). Medical Imaging: From Roentgen to the Digital Revolution, and Beyond. Rambam Maimonides medical journal, 9(4).

Bigler, E. D. (2014). Magnetic resonance imaging in the evaluation of cognitive function. Pediatric blood \& cancer, 61(10), 1724-1728.

Brown, B. H., \& Seagar, A. D. (1987). The Sheffield data collection system. Clinical Physics and Physiological Measurement, 8(4A), 91.

Brown, M. A., \& Semelka, R. C. (2011). MRI: basic principles and applications. John Wiley \& Sons.

Carlak, H. F., Gencer, N. G., \& Besikci, C. (2016). Theoretical assessment of electro-thermal imaging: A new technique for medical diagnosis. Infrared Physics \& Technology, 76, 227 234.

Chen, J.-J., Fu, S.-Y., Chiang, C.-S., Hong, J.-H., \& Yeh, C.-K. (2013). A preclinical study to explore vasculature differences between primary and recurrent tumors using ultrasound Doppler imaging. Ultrasound in medicine \& biology, 39(5), 860-869.

Chen, W., Sajadi, M. M., \& Dilsizian, V. (2018). Merits of FDG $\mathrm{PET} / \mathrm{CT}$ and functional molecular imaging over anatomic imaging with echocardiography and $\mathrm{CT}$ angiography for the diagnosis of cardiac device infections. JACC: Cardiovascular Imaging, 11(11), 1679-1691.

Cherepenin, V. A., Karpov, A. Y., Korjenevsky, A. V, Kornienko, V. N., Kultiasov, Y. S., Ochapkin, M. B., Trochanova, O. V, \& Meister, J. D. (2002). Three-dimensional EIT imaging of breast tissues: system design and clinical testing. IEEE transactions on medical imaging, 21(6), 662-667.

Cherkas, L. F., Carter, L., Spector, T. D., Howell, K. J., Black, C. M., \& MacGregor, A. J. (2003). Use of thermographic criteria to identify Raynaud's phenomenon in a population setting. The Journal of rheumatology, 30(4), 720-722.

Cherry, S. R. (2004). In vivo molecular and genomic imaging: new challenges for imaging physics. Physics in Medicine \& Biology, 49(3), R13.

Chitturi, V., \& Farrukh, N. (2019). Spatial resolution in electrical impedance tomography: A topical review. Journal of Electrical Bioimpedance, 8(1), 66-78.

Choi, J. W., van Rosendael, A. R., Bax, A. M., van den Hoogen, I. J., Gianni, U., Baskaran, L., Andreini, D., De Cecco, C. N., Earls, J., \& Ferencik, M. (2020). The Journal of Cardiovascular Computed Tomography year in review2019. Journal of Cardiovascular Computed Tomography.

Chua, S., Gnanasegaran, G., \& Cook, G. J. R. (2009). 
Miscellaneous cancers (lung, thyroid, renal cancer, myeloma, and neuroendocrine tumors): role of SPECT and PET in imaging bone metastases. Seminars in nuclear medicine, 39(6), 416-430.

Damadian, R. (1971). Tumor detection by nuclear magnetic resonance. Science, 171(3976), 1151-1153.

Damadian, R., Zaner, K., Hor, D., \& DiMaio, T. (1974). Human tumors detected by nuclear magnetic resonance. Proceedings of the National Academy of Sciences, 71(4), 1471-1473.

Davies, P., Yasin, S., Gates, S., Bird, D., \& Silvestre, C. (2019). Clinical scenarios of the application of electrical impedance tomography in paediatric intensive care. Scientific reports, 9(1), 1-8.

Dennis, M., Ugander, M., Kozor, R., \& Puranik, R. (2019). Cardiovascular Magnetic Resonance Imaging of Inherited Heart Conditions. Heart, Lung and Circulation.

Dhawan, A. P. (2011). Medical image analysis (C. 31). John Wiley \& Sons.

Di Nardo, D., Gambarini, G., Capuani, S., \& Testarelli, L. (2018). Nuclear magnetic resonance imaging in endodontics: a review. Journal of endodontics, 44(4), 536542.

Dirix, P., Haustermans, K., \& Vandecaveye, V. (2014). The value of magnetic resonance imaging for radiotherapy planning. Seminars in radiation oncology, 24(3), 151-159.

Dunne, R. M., O’Neill, A. C., \& Tempany, C. M. (2017). Imaging Tools in Clinical Research: Focus on Imaging Technologies. Içinde Clinical and Translational Science (ss. 157-179). Elsevier.

Eadie, L., Bagshaw, A., Bayford, R., Binnie, C., \& Holder, D. (2001). Electrical impedance tomography imaging of epileptic activity in humans. Neuroimage, 13(6), 1314.

Ehman, R. L., Hendee, W. R., Welch, M. J., Dunnick, N. R., Bresolin, L. B., Arenson, R. L., Baum, S., Hricak, H., \& Thrall, J. H. (2007). Blueprint for imaging in biomedical research. Radiology, 244(1), 12-27.

El Atta, M. M. A., Amer, T. A., Gaballa, G. M., \& El-Sayed, N. T. M. (2016). Multi-phasic CT versus dynamic contrast enhanced MRI in characterization of parotid gland tumors. The Egyptian Journal of Radiology and Nuclear Medicine, 47(4), 1361-1372.

Ergene, M. C., Bayrak, A., \& Ceylan, M. (2020). Tracking the injury recovery of professional football players with infrared thermography: Preliminary Study. Avrupa Bilim ve Teknoloji Dergisi, 207-213.

Ertürk, C. (2005). Karaciğer transplantasyonu sonrass hepatik arter komplikasyonlarının multidedektör bilgisayarl Tomografik anjiografi ile değerlendirilmesi.

Erturk, S. M., Johnston, C., Tempany-Afdhal, C., \& Van den Abbeele, A. D. (2009). Imaging Tools in Human Research. Içinde Clinical and Translational Science (ss. 87-104). Elsevier.

Faro, S. H., \& Mohamed, F. B. (2006). Functional MRI: basic principles and clinical applications. Springer Science \& Business Media.

Farrow, C., \& King, G. (2019). SPECT Ventilation Imaging in Asthma. Seminars in nuclear medicine, 49(1), 11-15.

Fikackova, H., \& Ekberg, E. (2004). Can infrared thermography be a diagnostic tool for arthralgia of the temporomandibular joint? Oral Surgery, Oral Medicine, Oral Pathology, Oral Radiology, and Endodontology, 98(6), 643-650.

Friedewald, S. M. (2017). Breast tomosynthesis: practical considerations. Radiologic Clinics, 55(3), 493-502.

Gabriel, M., Brennan, N. P., Peck, K. K., \& Holodny, A. I. (2014). Blood oxygen level dependent functional magnetic resonance imaging for presurgical planning. Neuroimaging Clinics, 24(4), 557-571.

Ganguly, D., Chakraborty, S., Balitanas, M., \& Kim, T. (2010). Medical Imaging: A Review. Içinde Communications in Computer and Information Science (C. 78, ss. 504-516). https://doi.org/10.1007/978-3-642-16444-6_63

Gharibkandi, N. A., \& Hosseinimehr, S. J. (2019). Radiotracers for imaging of Parkinson's disease. European journal of medicinal chemistry, 166, 75-89.

Giussani, A. (2013). Imaging in nuclear medicine. Springer.

Gleeson, F. V. (2008). Imaging in chest disease. Medicine, 36(3), 132-141.

Gomes, C. M., Abrunhosa, A. J., Ramos, P., \& Pauwels, E. K. J. (2011). Molecular imaging with SPECT as a tool for drug development. Advanced drug delivery reviews, 63(7), 547554.

Gray, G. A. (2002). A variational study of the electrical impedance tomography problem.

Gunderman, R. B. (2012). X-ray vision: the evolution of medical imaging and its human significance. Oxford University Press.

Hardy, J. D. (1934). The radiation of heat from the human body: I. An instrument for measuring the radiation and surface temperature of the skin. The Journal of clinical investigation, 13(4), 593-604.

Harvey, C. J., Pilcher, J. M., Eckersley, R. J., Blomley, M. J. K., \& Cosgrove, D. O. (2002). Advances in ultrasound. Clinical Radiology, 57(3), 157-177.

Hawkes, R. C., Holland, G. N., Moore, W. S., \& Worthington, B. S. (1980). Nuclear magnetic resonance (NMR) tomography of the brain: a preliminary clinical assessment with demonstration of pathology. Journal of Computer Assisted Tomography, 4(5), 577-586.

Hendee, W. R., \& Ritenour, E. R. (2003). Medical imaging physics. John Wiley \& Sons.

Hertz, S., Roberts, A., \& Evans, R. D. (1938). Radioactive Iodine as an Indicator in the Study of Thyroid Physiology. Proceedings of the Society for Experimental Biology and Medicine, 38(4), 510-513.

Hogg, P., Kelly, J., \& Mercer, C. (2015). Digital Mammography. Springer.

Holder, D. (2004). Electrical impedance tomography: methods, history and applications. CRC Press.

Hounsfield, G. N. (1973). Computerized transverse axial scanning (tomography): Part 1. Description of system. The British journal of radiology, 46(552), 1016-1022.

Hsiao, T.-Y., Wang, C.-L., Chen, C.-N., Hsieh, F.-J., \& Shau, Y.W. (2001). Noninvasive assessment of laryngeal phonation function using color Doppler ultrasound imaging. Ultrasound in medicine \& biology, 27(8), 1035-1040.

Jalalian, A., Mashohor, S. B. T., Mahmud, H. R., Saripan, M. I. B., Ramli, A. R. B., \& Karasfi, B. (2013). Computer-aided detection/diagnosis of breast cancer in mammography and ultrasound: a review. Clinical imaging, 37(3), 420-426.

Jensen, M., \& Wilhjelm, J. E. (2006). X-ray imaging: Fundamentals and planar imaging. Report.

Jezzard, P., Matthews, P. M., \& Smith, S. M. (2001). Functional MRI: an introduction to methods (C. 61). Oxford university press Oxford.

Kandlikar, S. G., Perez-Raya, I., Raghupathi, P. A., Gonzalez- 
Hernandez, J.-L., Dabydeen, D., Medeiros, L., \& Phatak, P. (2017). Infrared imaging technology for breast cancer detection-Current status, protocols and new directions. International Journal of Heat and Mass Transfer, 108, 2303-2320.

Kasban, H., El-Bendary, M. A. M., \& Salama, D. H. (2015). A comparative study of medical imaging techniques. International Journal of Information Science and Intelligent Systems, 4(2), 37-58.

Kothekar, E., Raynor, W. Y., Al-Zaghal, A., Jonnakuti, V. S., Werner, T. J., \& Alavi, A. (2019). Evolving role of PET/CTMRI in assessing muscle disorders. PET clinics, 14(1), 7179.

Koundal, D., Gupta, S., \& Singh, S. (2012). Computer-aided diagnosis of thyroid nodule: a review. International Journal of Computer Science and Engineering Survey, 3(4), 67.

Lahiri, B. B., Bagavathiappan, S., Jayakumar, T., \& Philip, J. (2012). Medical applications of infrared thermography: a review. Infrared Physics \& Technology, 55(4), 221-235.

Laifer-Narin, S. L., Genestine, W. F., Okechukwu, N. C., Hecht, E. M., \& Newhouse, J. H. (2018). The role of computed tomography and magnetic resonance imaging in gynecologic oncology. PET clinics, 13(2), 127-141.

Lauterbur, P. C. (1973). Image formation by induced local interactions: examples employing nuclear magnetic resonance. nature, 242(5394), 190-191.

Leandri, C., Soyer, P., Oudjit, A., Guillaumot, M.-A., Chaussade, S., Dohan, A., \& Barret, M. (2019). Contribution of magnetic resonance imaging to the management of esophageal diseases: A systematic review. European Journal of Radiology, 120, 108684.

Lecomte, R. (2009). Novel detector technology for clinical PET. European journal of nuclear medicine and molecular imaging, 36(1), 69-85.

Lee, Z., Nagano, K. K., Duerk, J. L., Sodee, D. B., \& Wilson, D. L. (2003). Automatic registration of MR and SPECT images for treatment planning in prostate cancer. Academic radiology, 10(6), 673-684.

Lemoigne, Y., Caner, A., \& Rahal, G. (2007). Physics for medical imaging applications (C. 240). Springer Science \& Business Media.

Livieratos, L. (2012). Basic principles of SPECT and PET imaging. Içinde Radionuclide and Hybrid Bone Imaging (ss. 345-359). Springer.

Lonzetti, L., Zanon, M., Pacini, G. S., Altmayer, S., de Oliveira, D. M., Rubin, A. S., Gazzoni, F. F., Barros, M. C., \& Hochhegger, B. (2019). Magnetic resonance imaging of interstitial lung diseases: A state-of-the-art review. Respiratory medicine.

Lozano III, A., \& Hassanipour, F. (2019). Infrared imaging for breast cancer detection: An objective review of foundational studies and its proper role in breast cancer screening. Infrared Physics \& Technology, 97, 244-257.

Lu, J., Sun, X., Yang, X., Tang, X., Qin, Q., Zhu, H., Cheng, H., $\&$ Sun, X. (2016). Impact of PET/CT on radiation treatment in patients with esophageal cancer: A systematic review. Critical reviews in oncology/hematology, 107, 128-137.

Mah, J. K., Huang, J. C., \& Choo, H. (2010). Practical applications of cone-beam computed tomography in orthodontics. The Journal of the American Dental Association, 141, 7S-13S.

Mandeville, E. T., Ayata, C., Zheng, Y., \& Mandeville, J. B. (2017). Translational MR neuroimaging of stroke and recovery. Translational stroke research, 8(1), 22-32.

Manginas, A., Andreanides, E., Leontiadis, V., Sfyrakis, P., Maounis, T., Degiannis, D., Alivizatos, P. A., \& Cokkinos, D. V. (2010). Right ventricular endocardial thermography in transplanted and coronary artery disease patients: first human application. Journal of Invasive Cardiology, 22(9), 400 .

Mansfield, P., \& Maudsley, A. A. (1977). Medical imaging by NMR. The British journal of radiology, 50(591), 188-194.

McCarville, M. B. (2015). Imaging techniques used in the diagnosis of pediatric tumors. Içinde Pediatric malignancies: Pathology and imaging (ss. 7-18). Springer.

McVeigh, E. R. (2006). Emerging imaging techniques. Circulation research, 98(7), 879-886.

Meola, M., Petrucci, I., \& Ronco, C. (2016). Ultrasound imaging in acute and chronic kidney disease. Karger Medical and Scientific Publishers.

Mettler Jr, F. A., \& Guiberteau, M. J. (2012). Essentials of Nuclear Medicine Imaging: Expert Consult-Online and Print. Elsevier Health Sciences.

Mikla, V. I., \& Mikla, V. V. (2013). Medical imaging technology. Elsevier.

Miwa, S., \& Otsuka, T. (2017). Practical use of imaging technique for management of bone and soft tissue tumors. Journal of Orthopaedic Science, 22(3), 391-400.

Moghaddam, K. K., Taheri, T., \& Ayubian, M. (2008). Bone structure investigation using X-ray and neutron radiography techniques. Applied Radiation and Isotopes, 66(1), 39-43.

Mourad, C., Omoumi, P., Malghem, J., \& Berg, B. C. Vande. (2019). Conventional Radiography of the Hip Revisited: Correlation with Advanced Imaging. Magnetic Resonance Imaging Clinics, 27(4), 661-683.

Nguyen, D. T., Jin, C., Thiagalingam, A., \& McEwan, A. L. (2012). A review on electrical impedance tomography for pulmonary perfusion imaging. Physiological measurement, 33(5), 695.

Niklason, L. T., Christian, B. T., Niklason, L. E., Kopans, D. B., Castleberry, D. E., Opsahl-Ong, B. H., Landberg, C. E., Slanetz, P. J., Giardino, A. A., \& Moore, R. (1997). Digital tomosynthesis in breast imaging. Radiology, 205(2), 399406.

Noble, J. M., \& Scarmeas, N. (2009). Application of Pet Imaging to Diagnosis of Alzheimer's Disease and Mild Cognitive Impairment1. International review of neurobiology, 84, 133-149.

Ørnbjerg, L. M., \& Østergaard, M. (2020). Assessment of structural damage progression in established rheumatoid arthritis by conventional radiography, computed tomography, and magnetic resonance imaging. Best Practice \& Research Clinical Rheumatology, 101481

Pallaver, A., \& Honigmann, P. (2019). The Role of Cone-Beam Computed Tomography (CBCT) Scan for Detection and Follow-Up of Traumatic Wrist Pathologies. The Journal of hand surgery.

Park, J.-Y., Hyun, J. K., \& Seo, J.-B. (2007). The effectiveness of digital infrared thermographic imaging in patients with shoulder impingement syndrome. Journal of shoulder and elbow surgery, 16(5), 548-554.

Park, J. M., Franken Jr, E. A., Garg, M., Fajardo, L. L., \& Niklason, L. T. (2007). Breast tomosynthesis: present considerations and future applications. Radiographics, 27(suppl_1), S231-S240.

Penaloza, T. Y. M., Karkhanis, S., Kvaal, S. I., Nurul, F., 
Kanagasingam, S., Franklin, D., Vasudavan, S., Kruger, E., \& Tennant, M. (2016). Application of the Kvaal method for adult dental age estimation using Cone Beam Computed Tomography (CBCT). Journal of forensic and legal medicine, 44, 178-182.

Poeppel, T. D., Krause, B. J., Heusner, T. A., Boy, C., Bockisch, A., \& Antoch, G. (2009). PET/CT for the staging and follow-up of patients with malignancies. European journal of radiology, 70(3), 382-392.

Polat, A., \& Yildirim, I. (2018). An iterative reconstruction algorithm for digital breast tomosynthesis imaging using real data at three radiation doses. Journal of $X$-ray science and technology, 26(3), 347-360.

Qureshi, N. R., \& Gleeson, F. V. (2006). Imaging of pleural disease. Clinics in chest medicine, 27(2), 193-213.

Radon, J. (2005). 1.1 über die bestimmung von funktionen durch ihre integralwerte längs gewisser mannigfaltigkeiten. Classic papers in modern diagnostic radiology, 5, 21.

Ring, E. F. J. (2007). The historical development of temperature measurement in medicine. Infrared physics \& technology, 49(3), 297-301.

Ring, F. (2010). Thermal imaging today and its relevance to diabetes. SAGE Publications.

Romans, L. (2018). Computed Tomography for Technologists: A comprehensive text. Lippincott Williams \& Wilkins.

Rubia, K. (2013). Functional brain imaging across development. European child \& adolescent psychiatry, 22(12), 719-731.

Samei, E. (2020). Computed Tomography: Approaches, Applications, and Operations. Springer Nature.

Samei, E., \& Peck, D. J. (2019). Hendee's Physics of Medical Imaging. John Wiley \& Sons.

Scott, S., \& Messer, B. (2018). Critical care chest radiology. Surgery (Oxford), 36(12), 694-698.

Semelka, R. C., \& Elias, J. (2013). Health care reform in radiology (C. 7). Wiley Online Library.

Shamim, S. A., Torigian, D. A., \& Kumar, R. (2008). PET, $\mathrm{PET} / \mathrm{CT}$, and PET/MR imaging assessment of breast cancer. PET clinics, 3(3), 381-393.

Shevelev, I. A. (1998). Functional imaging of the brain by infrared radiation (thermoencephaloscopy). Progress in neurobiology, 56(3), 269-305.

Shung, K. K. (2015). Diagnostic ultrasound: Imaging and blood flow measurements. CRC press.

Sidden, C. R., \& Mortele, K. J. (2007). Cystic tumors of the pancreas: ultrasound, computed tomography, and magnetic resonance imaging features. Seminars in Ultrasound, CT and MRI, 28(5), 339-356.

Simard, R. (2020). Ultrasound Imaging of Orthopedic Injuries. Emergency Medicine Clinics, 38(1), 243-265.

Smith, N. B., \& Webb, A. (2010). Introduction to medical imaging: physics, engineering and clinical applications. Cambridge university press.

Sniegowski, M., Erlanger, M., Velez-Montoya, R., \& Olson, J. L. (2015). Difference in ocular surface temperature by infrared thermography in phakic and pseudophakic patients. Clinical ophthalmology (Auckland, NZ), 9, 461.

Sørensen, A., \& Sinding, M. (2020). Placental Magnetic Resonance Imaging: A Method to Evaluate Placental Function In Vivo. Obstetrics and Gynecology Clinics, 47(1), 197-213.

Sousa, E., Vardasca, R., Teixeira, S., Seixas, A., Mendes, J., \& Costa-Ferreira, A. (2017). A review on the application of medical infrared thermal imaging in hands. Infrared Physics
\& Technology, 85, 315-323

Stabile, A., Giganti, F., Kasivisvanathan, V., Giannarini, G., Moore, C. M., Padhani, A. R., Panebianco, V., Rosenkrantz, A. B., Salomon, G., \& Turkbey, B. (2020). Factors Influencing Variability in the Performance of Multiparametric Magnetic Resonance Imaging in Detecting Clinically Significant Prostate Cancer: A Systematic Literature Review. European Urology Oncology.

Stefanesco, S., Schlumberger, C., \& Schlumberger, M. (1930). Sur la distribution électrique potentielle autour d'une prise de terre ponctuelle dans un terrain à couches horizontales, homogènes et isotropes. Journal de Physique et le Radium, 1(4), 132-140.

Sundaram, N., Bosley, J., \& Stacy, G. S. (2013). Conventional radiographic evaluation of athletic injuries to the hand. Radiologic Clinics, 51(2), 239-255.

Sung, E. K., Setty, B. N., \& Castro-Aragon, I. (2012). Sonography of the pediatric scrotum: emphasis on the Tstorsion, trauma, and tumors. American Journal of Roentgenology, 198(5), 996-1003.

Szabo, T. L. (2004). Diagnostic ultrasound imaging: inside out. Academic Press.

Tagliafico, A., Houssami, N., \& Calabrese, M. (2016). Digital breast tomosynthesis: a practical approach. Springer.

Ülman, Y. I., \& Olay, T. B. (2006). Ülkemiz ve Dünya Radyolojisine Katkılarlyla Dr. Esad Feyzi. Doktor.

Van der Vaart, M. G., Meerwaldt, R., Slart, R., van Dam, G. M., Tio, R. A., \& Zeebregts, C. J. (2008). Application of PET/SPECT imaging in vascular disease. European Journal of Vascular and Endovascular Surgery, 35(5), 507-513.

Virmani, J., Kumar, V., Kalra, N., \& Khandelwal, N. (2014). Neural network ensemble based CAD system for focal liver lesions from B-mode ultrasound. Journal of digital imaging, 27(4), 520-537.

Vollmer, M., \& Möllmann, K.-P. (2017). Infrared thermal imaging: fundamentals, research and applications. John Wiley \& Sons.

Wachsmann, J. W., \& Gerbaudo, V. H. (2014). Thorax: normal and benign pathologic patterns in FDG-PET/CT imaging. PET clinics, 9(2), 147-168.

Wang, L. H., McKenzie-Brown, A. M., \& Hord, A. (2006). The Handbook of C-Arm Fluoroscopy-Guided Spinal Injections. CRC Press.

Wei, S. C., Ulmer, S., Lev, M. H., Pomerantz, S. R., González, R. G., \& Henson, J. W. (2010). Value of coronal reformations in the CT evaluation of acute head trauma. American journal of neuroradiology, 31(2), 334-339.

Wintermark, P. (2012). The role of brain MRI scanning in the newborn. Paediatrics and Child Health, 22(4), 155-159.

Wolbarst, A. B., \& Hendee, W. R. (2006). Evolving and experimental technologies in medical imaging. Radiology, 238(1), 16-39.

Xiao-Xue, W., Xinyue, H., \& Lijun, Z. (2019). Whole body FDG-PET/CT for the assessment of bone marrow infiltration in patients with newly diagnosed lymphoma. Medicina clinica.

Yoon, M.-J., Kim, E., Lee, S.-J., Bae, Y.-M., Kim, S., \& Park, S.H. (2010). Pulpal blood flow measurement with ultrasound Doppler imaging. Journal of endodontics, 36(3), 419-422.

Young, P. M., Foley, T. A., Araoz, P. A., \& Williamson, E. E. (2019). Computed tomography imaging of cardiac masses. Radiologic Clinics, 57(1), 75-84.

Zaucha, J. M., Chauvie, S., Zaucha, R., Biggii, A., \& Gallamini, 
A. (2019). The role of PET/CT in the modern treatment of Hodgkin lymphoma. Cancer treatment reviews.

Zhang, N., Dong, H., Wang, P., Wang, Z., Wang, Y., \& Guo, Z. (2020). The value of obstetric ultrasound in screening fetal nervous system malformation. World Neurosurgery.

Zhang, W., Zhao, J., Jiang, X., Li, L., Yu, C., Zhao, Y., \& Si, H. (2020). Thoracic vertebra fixation with a novel screw-plate system based on computed tomography imaging and finite element method. Computer Methods and Programs in Biomedicine, 187, 104990.

Zhao, W., Zhong, Z., Xie, X., Yu, Q., \& Liu, J. (2020). Relation between chest $\mathrm{CT}$ findings and clinical conditions of coronavirus disease (COVID-19) pneumonia: a multicenter study. American Journal of Roentgenology, 214(5), 10721077.

Zou, Y., \& Guo, Z. (2003). A review of electrical impedance techniques for breast cancer detection. Medical engineering \& physics, 25(2), 79-90. 